\title{
Mit tudunk a pókok (Araneae) cirkadián ritmusairól? - Ökológiai vonatkozások, vizsgálati módszerek és adatelemzési eljárások
}

\author{
MEZŐFI LÁSZLó \\ Növényvédelmi Intézet, Szent István Egyetem, 1118 Budapest, Ménesi út 44. \\ E-mail:mezofilaszlo@gmail.com
}

\begin{abstract}
Összefoglalás. Kronobiológiai áttekintésünkben bevezetjük az olvasót a biológiai ritmusok kutatásának rejtelmeibe. Munkánkban először a tudományterület fontosabb szabályait és szakkifejezéseit (terminus technikus-ait) ismertetjük, majd az élőlények különböző napszakokhoz történő alkalmazkodásának ökológiai jelentőségét és változatait tárgyaljuk. Ezután részletesebben bemutatjuk, hogy mit tudunk a pókok (Araneae) aktivitási ritmusairól és napszakos aktivitásáról, illetve, a csoport példáin keresztül azt is, hogy ezek a ritmusok milyen módszerekkel vizsgálhatók laboratóriumban és szabadföldön. Végezetül, alapozó jelleggel végigvesszük, hogy milyen módszerek/adatelemzési eljárások alkalmasak a különböző biológiai ritmusok értékelésére.
\end{abstract}

Kulcsszavak: napszakos aktivitás, lokomotoros aktivitás, kronobiológia, pókok, aktivitási típusok.

Elfogadva: 2020.06.13.

Elektronikusan megjelent: 2020.06.25.

\section{Bevezetés}

\section{Kronobiológia}

A fiziológiai folyamatokban illetve a viselkedésben végbemenő változások általában ciklikusan, egyfajta ritmust követve zajlanak. Ez a pókokra nézve ugyanúgy igaz, mint minden más állatra nézve (CLOUDSLEY-THOMPSON 1987, WATTS et al. 2015). A hozzávetőleg 24 órás periódusú ritmusokat, melyeket egy úgynevezett belső „óra” - mely egyfajta hipotetikus mechanizmus az agyban, vagy egyéb szervben - vezérel, cirkadián (azaz napi) ritmusoknak nevezzük (PITTENDRIGH 1960, MILls 1973). A napi ritmusok mellett megkülönböztetünk még ultradián (24 óránál rövidebb periódusidővel rendelkező, például tidális, azaz ár-apály ritmus) és infradián (egy napnál hosszabb periódusidővel rendelkező, például lunáris vagy annuális) ritmusokat is (ASCHOFF 1981). Az ízeltlábúak esetében a biológiai ritmusok megnyilvánulnak például a lokomotoros (mozgási) aktivitásukban, de befolyással vannak a táplálkozásra, légzésre, kiválasztásra és a reprodukciós tevékenységre egyaránt. A ritmus tetten érhető úgy a lárváknál, mint a kifejlett alakoknál, befolyással van a vedlés, vagy a bábból való kikelés időpontjára is. A ritmusok biztosítják, hogy az állat bizonyos életfunkcióit a nap (vagy év) arra leginkább megfelelő időszakában végezze el (HARKER 1973, SAUNDERS 2002, DANKS 2003, LAZZARI \& INSAUSTI 2008). 
A legtöbb biológiai ritmus egy erős endogén komponenssel rendelkezik, mely kifejeződését változó mértékben befolyásolja a környezet (exogén) hatása (ASCHOFF 1989, LAZZARI \& INSAUSTI 2008). A ritmusokat általában a belső óra vezérli - mely óra molekuláris mechanizmusai mostanra viszonylag jól feltártak (például Ko \& TAKAHASHI 2006) -, amit sokszor exogén szinkronizáló stimulusok hangolnak finomra. Ezeket a stimulusokat Zeitgeber-nek (szabad fordításban „időzítö”) is szokták nevezni. A szinkronizáló stimulusok általában 24 órás (ún. nychthemeral) ritmusú külső tényezők, mint például a fény és a sötétség konzisztens oszcillációja (MILLS 1973). A ritmusok szinkronizációjában egyéb tényezők is szerepet játszhatnak (MROSOVSKY 1996, STEPHAN 2002). Vízhez közeli életmódú ízeltlábúak esetében például az árapály változása is lehet szinkronizáló tényező, illetve közvetlen kiváltója egyes tevékenységeknek (GOTO \& TAKEKATA 2015, SAKURA \& NUMATA 2017). Fontos itt megjegyezni, hogy a tapasztalt ritmusra alapvetően kétféle úton hathatnak az exogén tényezők. A belső óra beállításához idő kell, azt nem lehet beállítani vagy elállítani egyszeri vagy esetleges stimulusokkal, sőt, az óra sokszor csak a nap bizonyos szakaszaiban fogékony a beállításra. Normális körülmények között a rendszeresen ismétlődő környezeti ingerek megfelelően állítják be a belső órát, így az biztosítja a megfigyelt ritmus pontos müködését. Ez a belső óra (vagy ritmus) szinkronizációja (entrainment) (MINORS \& WATERHOUSE 1986). Az exogén stimulusok közvetlenül is hathatnak a ritmusra, ezt nevezik „maszkolásnak” (masking, azaz elfedik a belső óra szabályozó hatását). Ez a közvetlen hatás lehet például pozitív (positive masking) vagy negatív (negative masking). Elöbbi esetben az aktivitás növekszik a megvilágítás növekedésével a nappali állatoknál, vagy a megvilágítás csökkenésével az éjszakai állatoknál. Negatív hatásról akkor beszélünk, ha az aktivitás csökken a megvilágítás csökkenésével a nappali állatoknál, vagy a megvilágítás növekedésével az éjszakai állatoknál (MROSOVSKY 1999).

A jól szinkronizált endogén ritmusok segítik az állatokat abban, hogy a különböző környezeti paraméterek periodikus váltakozására ne csupán reaktívan válaszoljanak, hanem elörelátóan, úgynevezett proaktív módon is, ugyanis így képesek a környezet változását például napkeltét vagy napnyugtát - „elöre érzékelni” és bizonyos funkciókat még a változás előtt végrehajtani (JONES et al. 2011, 2018). A napon belüli megvilágítás, vagyis a fotoperiódus hossza (LD, vagyis light/dark arány) meghatározó jelentőségü számos ízeltlábú számára. A nappalhossz növekedését vagy csökkenését az ízeltlábúak ritmusai is követik, sőt, például ősszel a nappalhossz rövidülése váltja ki számos ízeltlábúból a diapauzát, vagyis ez az inger ösztönzi öket a nyugalmi állapotba vonulásra, így csökkentve a téli mortalitást (LAZZARI \& INSAUSTI 2008, SAUNDERS 2002, 2012). Ezzel összefüggésben, egyes mérsékelt övi pókfajok is lelassítják vagy felfüggesztik bizonyos élettevékenységeiket. Juvenilis egyedeik rövidnappalos körülmények között még megfelelö hőmérséklet és zsákmányellátottság esetén is csak később, vagy akár egyáltalán nem vedlenek (KISS \& SAMU 2002, VETTER et al. 2017).

A fény szabályozó hatása nélkül az endogén cirkadián periódus hossza szintén különbözhet attól függően, hogy az élölény konstans sötétségben (DD, dark/dark) vagy éppen fényben (LL, light/light) van. Az adott ritmus periódusideje hosszabbodhat, vagy rövidülhet, esetleg a ritmus csak bizonyos körülmények között marad detektálható. Sőt, a periódus idejére a megvilágítási idő mellett a fény intenzitásának is közvetlen hatása lehet (KOUKKARI \& SOTHERN 2006). Az utóbb említett körülményekre vonatkozó általános szabályokat, - melyek alól ma már számos kivételt ismerünk - a kronobiológia tudományterü- 
let egyik atyjának tartott, JÜRGEN ASCHOFF német orvos és biológus munkássága nyomán fogalmazták meg (ASCHOFF 1960, 1979, BEAULÉ 2009). A szabályrendszer a következő:

Konstans körülmények között (DD, LL) az endogén cirkadián periódus mindig megcsúszik, úgynevezett „szabadon futó” (free-running) lesz. A csúszás mértékére és irányára vonatkozó szabályok pedig a következők:

- Aschoff első szabálya: LL-ben a periódusidő a nappali állatok esetében lerövidül, míg éjszakai állatok esetében meghosszabbodik. Az LL hatása egyben intenzitásfüggő is, mivel a fényesebb megvilágítás fokozza a hatást.

- Aschoff második szabálya (más néven cirkadián szabály): LL-ben a nappali állatoknál a fényintenzitás fokozására az aktivitás ideje növekszik a nyugalmi időhöz képest, míg az éjszakai állatok esetében fényintenzitás fokozására az ébrenlét/alvás arány csökken.

- Aschoff harmadik szabálya: DD-ben a szabadon futó periódus a nappali állatok esetében 24 óránál hosszabb, míg az éjszakai állatok esetében 24 óránál rövidebb lesz.

\section{Célkitüzés}

Jelen dolgozat célkitüzései a következők: (1) megismertetni az olvasóval a kronobiológia tudományterületének fontosabb szabályszerüségeit; (2) tisztázni az egyes szakkifejezések jelentését; (3) bemutatni az élőlények típusait a különböző napszakokhoz történő alkalmazkodásuk szempontjából; (4) összefoglalni a pókok napszakos aktivitásáról és biológiai ritmusairól eddig felgyült ismeretanyagot; (5) ismertetni az aktivitási ritmusok vizsgálatára alkalmas különböző laboratóriumi és szabadföldi módszereket; (6) áttekintést adni a biológiai ritmusok értékelésére alkalmas fontosabb adatelemzési eljárásokról; és végezetül (7) megfogalmazni a pókok biológiai ritmusaival kapcsolatos megválaszolásra váró kérdéseket és új kutatási irányokat.

\section{A napszakos aktivitás jellemzői}

Ökológiai szempontból fontos kérdés, hogy egy élőlénynek milyen a napi aktivitási ritmusa. A különböző temporális (időbeli) nichekhez való adaptáció alapvetően meghatározza, hogy az adott élőlény számára milyen források lesznek elérhetőek, illetve, hogy milyen ragadozókkal vagy kompetítorokkal találkozhat (SIH et al. 2000, KRONFELD-SCHOR \& DAYAN 2003, WELCH \& HARWOOD 2014, XimEnEZ-EMBUN et al. 2014). Például a Micaria sociabilis (Araneae: Gnaphosidae) hangyautánzó pókfaj nappali aktivitású, mint az utánzott fajok, annak ellenére, hogy a pók közeli rokonai mind éjszaka aktívak. Habár a pók nem hangyákkal táplálkozik, a velük való együttes előfordulása úgy tünik, hogy defenzív adaptív előnyt biztosít (például védelmet a hangyákat kerülő ragadozóktól) a pók számára (PEKÁR \& JARAB 2011).

A napi ritmusuk (diel rhythm) vagy napszakos aktivitásuk szerint a következők lehetnek az élölények: Az éjszakai (nocturnal - nokturnális) fajok a szkotofázisban, azaz sötétségben, éjszaka aktívak, míg a nappali (diurnal - diurnális) fajok a fotofázisban, azaz nappal aktívak (MILLS 1973). Ha az aktivitás csak a hajnali szürkülethez köthető, akkor azt matutinal (az entomológiában jellemzően matinal), ha csak az alkonyati szürkülethez, ak- 
kor azt vespertine aktivitásnak hívjuk. Azok a fajok, melyek egyszerre mutatnak matutinal és vespertine aktivitást, - vagyis a hajnali és alkonyati szürkületben egyaránt aktívak krepuszkuláris (crepuscular) aktivitásúak, de szimplán csak a hajnali, vagy csak az alkonyati szürkületi aktivitást is szokták az utóbbi kifejezéssel illetni (WCISLO \& TIERNEY 2009, BATISTA et al. 2011, REFINETTI 2016). Az olyan fajokat, melyeknél az aktivitás hozzávetőleg egyenletesen oszlik el a nap 24 órájában, vagy napszakhoz nem köthetően szórványosan, illetve szabálytalan idöközönként aktívak, katemerális (cathemeral vagy around-theclock activity) aktivitásúnak nevezzük (TATTERSALL 1987). Utóbbi állatokra jellemző a gyenge, illetve nehezen megfigyelhető cirkadián ritmus, tevékenységüket esetleg csak ultradián ritmusok alakítják, vagy teljesen aritmikusak (BLOCH et al. 2013).

Az állatok aktivitási ritmusának leggyakoribb hullámformája általában kétcsúcsú (vagyis bimodális), ami azt jelenti, hogy a hajnali és az alkonyati fokozott aktivitás meglehetősen gyakori (ASCHOFF 1966, REFINETTI 2016). Így bizonyos értelemben elmondható, hogy a nappali állatok a napkeltei és napnyugtai csúcsok között is aktívak, míg az éjszakai állatok a napnyugtai és napkeltei csúcsok között (REFINETTI 2016). Gyakori, hogy az ilyen kétcsúcsú aktivitási görbét mutató állatok esetében a nappali állatoknál az aktivitási csúcsok közvetlenül a virradat után, illetve az alkonyat előtt jelennek meg. Számos éjszakai állat esetében viszont az aktivitási görbe maximumai a napnyugtát követően és a napkeltét megelözően mutatkoznak. Ezeket a kétcsúcsú aktivitási mintázatokat eokrepuszkuláris aktivitásnak (eocrepuscular) is nevezik (PITTENDRIGH 1981). A tisztán krepuszkuláris állatok azok, amelyek a napkeltei és/vagy napnyugtai aktivitásuk melletti esetleges aktivitásukkal nem tüntetik ki egyértelmüen sem az éjszakát vagy a nappalt, az következetlenül oszlik el a két napszak között (REFINETTI 2016).

Megjegyzendö, hogy még az olyan fajok esetén is, melyeket egyértelmüen nappalinak vagy éjszakainak tartanak, egyes egyedek a többi egyedtől eltérően teljesen más aktivitást mutathatnak. Sőt, bizonyos környezeti körülmények (például évszak vagy extrém hőmérsékleti viszonyok) és ökológiai szituációk (például ragadozó-, vagy versenytársjelenlét) hatására egyes fajok egyedeinél (vagy populációinál) megváltozhat az aktivitási mintázat, viselkedhetnek akár nappaliként, akár éjszakai állatként is (KRONFELD-SCHOR \& DAYAN 2003, HUT et al. 2011, 2012, REFINETTI 2016). Mivel a ritmus szinkronizációjának szempontjából a fény hatása általában meghatározó, ezért a fotóperiódus hosszának változásával változhat az aktivitási mintázat (HOPE \& JONES 2013, ENSING et al. 2014). Az évszakos hatásokra egy szélsőséges példa a sebes pisztráng (Salmo trutta, Salmoniformes: Salmonidae) Arktikus régióban mutatott aktivitási mintázata. A faj aktivitása határozottan bimodális, egy virradatot és egy napnyugtát követő csúccsal, azonban a tél közepén az aktivitási mintázat mégis unimodális és nappali, míg a nyár közepén szintén unimodális, de éjszakai lesz. Mindez a fotóperiódus hosszának drasztikus változására vezethető vissza (PITTENDRIGH 1981).

Tehát a cirkadián ritmusok egyes fajok esetén különbözőek a specifikus adaptációból adódóan, mely a különböző források kiaknázására, vagy épp a kedvezőtlen feltételek és predátorok elkerülésére irányul. Unimodális és bimodális aktivitási eloszlások egyaránt megfigyelhetőek mind az éjszakai, mind a nappali fajoknál (LAZZARI \& INSAUSTI 2008). 


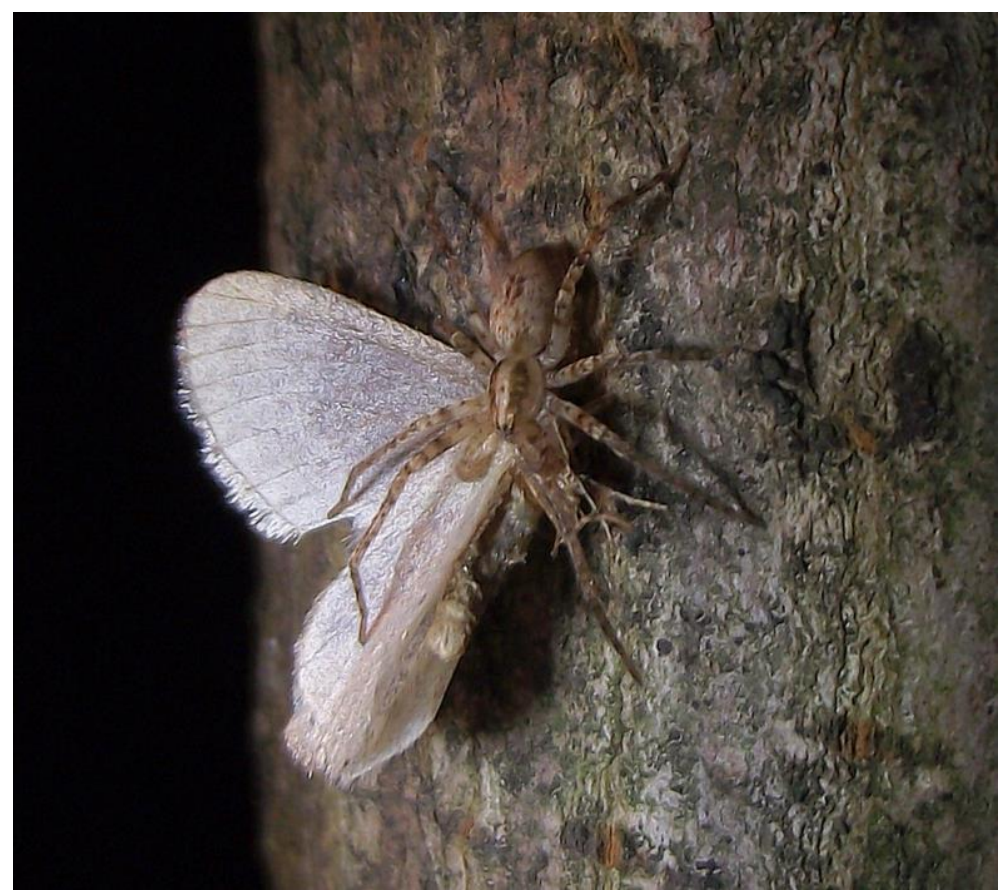

1. ábra. Anyphaena accentuata (Anyphaenidae) Operophtera brumata (Geometridae) imágót zsákmányol. Mindkét faj a naplemente utáni órákban a legaktívabb. (Fotó: KORÁNYI DÁVID)

Figure 1. Anyphaena accentuata (Anyphaenidae) preying on an Operophtera brumata (Geometridae) adult. Both species are most active after sunset. (Photo by DÁVID KORÁNYI)

\section{A pókok napszakos aktivitása}

Mivel a pókok általában azt a zsákmányt ejtik el, mellyel az aktív periódusukban találkoznak (MALONEY et al. 2003), ezért a pókok napszak szerinti aktivitása fontos predációt meghatározó tényező (1. ábra). A napszakos aktivitás, és az aktivitási mintázat potenciálisan befolyásolhatja az adott faj zsákmányspektrumának összetételét, így például mezőgazdasági területeken azt is, hogy milyen kártevő, vagy kártevők gyérítésében lehet egy konkrét fajnak aktív szerepe (MORSE 1981, HERBERSTEIN \& ELGAR 1994, MARC et al. 1999, TIETJEN \& CADY 2007). A pókok többsége éjszaka aktív (CLOUDSLEY-THOMPSON 2000, FOELIX 2011,2. ábra), egy hipotézis szerint részben azért, mert ilyenkor jóval kisebb a madarak és egyéb ragadozók predációs nyomása (FOELIX 2011, MESTRE et al. 2013). A nappali fajoknak nem csak számos ragadozóhoz, de az UV sugárzáshoz is alkalmazkodniuk kellett, így a nappal aktív hálószövő fajok pókselyme ellenállóbb az UV sugarakkal szemben, mint az éjszakaiaké (OSAKI \& OSAKI 2011). Nappali aktivitású fajokat elsősorban az ugrópókok (Salticidae) (3.a ábra), hiúzpókok (Oxyopidae), karolópókok (Thomisidae) és farkaspókok (Lycosidae) családjaiban találhatunk (FoELIX 2011). Emellett vannak olyan fajok is (például Avicularia avicularia: Theraphosidae), melyek bimodális szürkületi aktivi- 
tást mutatnak, azaz krepuszkuláris aktivitásúak (CLOUDSLEY-THOMPSON 1987). Egyes fajok (például Aphonopelma sp.: Theraphosidae; Geolycosa domifex: Lycosidae) jellemzően inkább inaktívak és nem figyelhető meg náluk jelentős lokomotoros aktivitási ritmus, vagy épp a nap 24 órájában bármikor aktívak lehetnek (például Philodromus cespitum: Philodromidae), azaz katemerális aktivitásúak (CLOUDSLEY-THOMPSON 1981, MCQUEEN \& CULIK 1981, MEZÖFI et al. 2019) (3.b ábra). SORIANO-MORALES et al. (2013) mexikói barlangokban teljes sötétségben élö fajokat (Euagrus luteus: Dipluridae; Ctenus mitchelli: Ctenidae) vizsgálva megállapították, hogy ezek a fajok is rendelkeznek egyfajta ,szabadon futó" cirkadián lokomotoros aktivitási ritmussal. A periódus konstans sötétségben (DD) $25,18 \pm 0,75$ óra hosszúságú, míg az egyedeket LD (12:12) körülmények közé helyezve a ciklus $24,12 \pm 0,29$ óra hosszúságúra rövidült a fény szabályozó hatása révén. A fény - mint elsődleges külső szinkronizáló - közvetlen szabályozó hatására (masking) jó példa a Metepeira incrassata (Araneidae) szociális pókfaj teljes napfogyatkozás alatt mutatott viselkedése. Az egyedek normális esetben reggel építik a hálójukat és este, sötétedéskor elbontják azt. A napfogyatkozás alatt a pókok többsége elkezdte lebontani a hálóját, majd miután kivilágosodott, a pókok megjavították a fogóhálót és folytatták nappali tevékenységüket (UETZ et al. 1994). Számos keresztespókféle kifejezetten csak éjszaka aktív (JONES et al. 2018). Például a Larinia fajok (Araneidae) egyedei a nap folyamán rejtőzködnek, majd szigorúan csak napnyugta után készítik el fogóhálójukat, melyet még a napkelte elött lebontanak, így teljesen láthatatlannak maradva a nappali ragadozók számára. Éjszaka, ha mesterséges fénnyel világítjuk meg a pókokat, rövid időn belül elkezdik a háló lebontását, majd a búvóhely keresését (SZINETÁR 2000, SZINETÁR \& EICHARDT 2004).

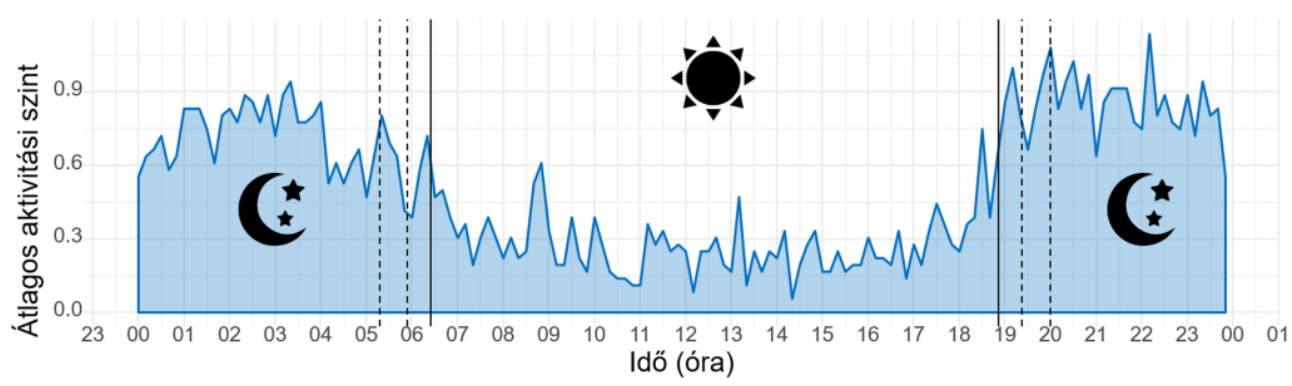

2. ábra. Egy éjszaka aktív pókfaj, a Cheiracanthium mildei (Cheiracanthiidae) egyedeinek $(\mathrm{N}=12)$ aktivitási profilja (3 nap átlaga). A függőleges vonalak a különböző szürkületi periódusokat jelzik, melyek a következők: navigációs szürkület kezdete, polgári szürkület kezdete, napkelte, napnyugta, polgári szürkület vége, navigációs szürkület vége. (Forrás: MEZÖFI L., nem publikált adatok)

Figure 2. Activity profile (average of three days) of individuals $(\mathrm{N}=12)$ of a nocturnal spider, Cheiracanthium mildei (Cheiracanthiidae). The vertical lines indicate the different twilight periods as follow: nautical dawn, civil dawn, sunrise, sunset, civil dusk and nautical dusk. (Source: MEZŐFI L., unpublished data)

A pókok között egyaránt találhatunk negatív- (például éjszakai fajoknál) és pozitív fototaxisú (például nappali fajoknál) taxonokat (NAKAMURA \& YAMASHITA 1997). Azonban nem a fototaxis dönti el, hogy az adott faj nappali, vagy éjszakai lesz-e. A Larinioides 
sclopetarius (Araneidae) keresztespókfaj bár éjszaka aktív, fogóhálóját a Larinia fajokkal ellentétben, ha teheti, fényforrások közelében készíti el. Az, hogy a mesterséges éjszakai megvilágítás nem zavarja, lehetővé tette a faj számára, hogy a nappali ragadozókat elkerülve használja ki a pozitív fototaxist mutató rovartáplálékot (HEILING \& HERBERSTEIN 1998, HEILING 1999).

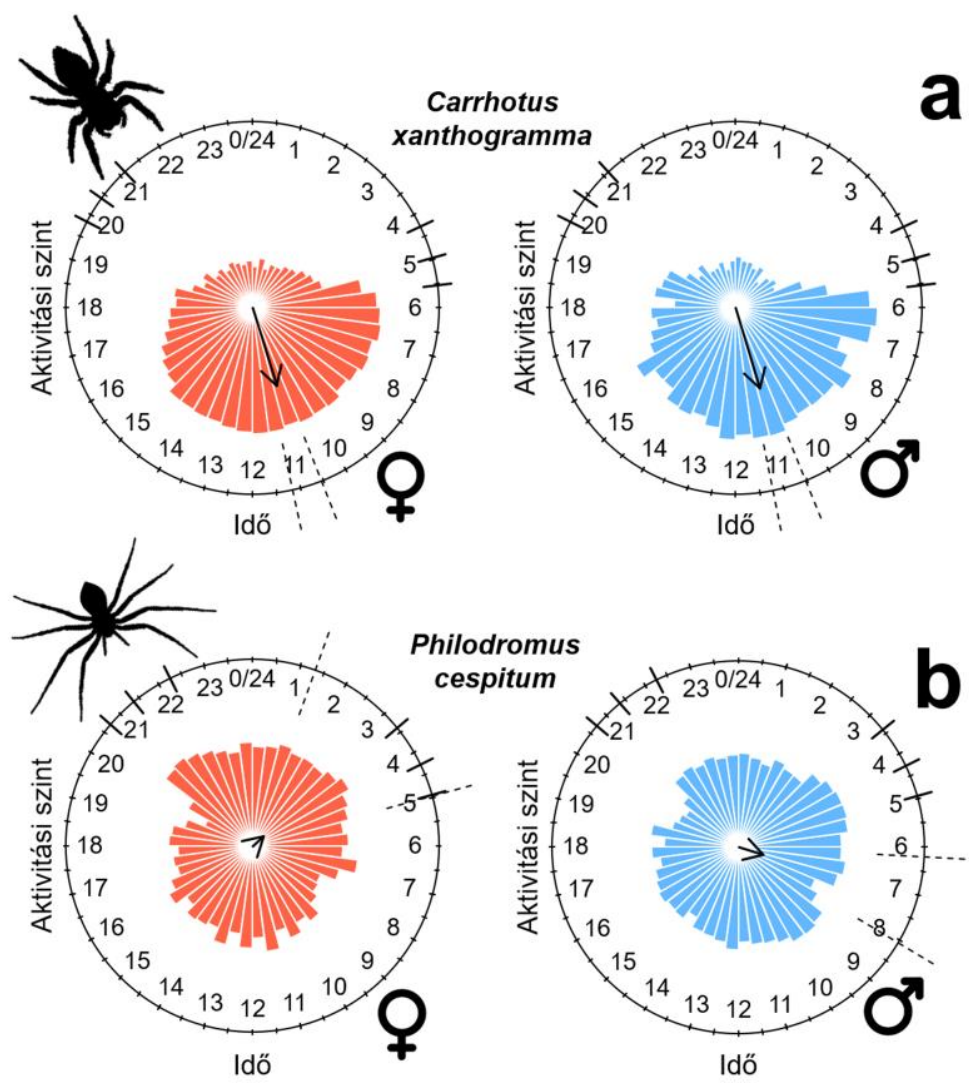

3. ábra. Carrhotus xanthogramma (Salticidae) (a) és Philodromus cespitum (Philodromidae) (b) nőstények (baloldalt, $\mathrm{N}=10$ és 11) és hímek (jobboldalt, $\mathrm{N}=10$ és 9) aktivitási mintázata ( 3 nap átlaga). Középen a nyíl jelzi az átlagos aktivitási csúcsot, hossza az átlagos rezultáns hossznak felel meg. Az aktivitási szint gyök transzformáltját 30 perces felbontásban ábrázoltuk. A szaggatott vonalak jelzik az átlagos aktivitási csúcs 95\%-os konfidencia intervallumát. A hat rövidebb vonal a különbözö szür-

kületi periódusokat jelzi, melyek a következők: navigációs szürkület kezdete, polgári szürkület kezdete, napkelte, napnyugta, polgári szürkület vége, navigációs szürkület vége.

(Forrás: MEZÖFI et al. 2019)

Figure 3. The activity pattern (average of three days) of Carrhotus xanthogramma (Salticidae) (a) and Philodromus cespitum (Philodromidae) (b) females (left, $\mathrm{N}=10$ and 11) and males (right, $\mathrm{N}=10$ and 9). The mean activity peak (circular mean) is indicated by the arrow and its length is related to the mean resultant length. The square-root of the level of activity was plotted at $30 \mathrm{~min}$ intervals. Dashed lines indicate the $95 \%$ confidence intervals of the mean peak activity and the six shorter solid lines indicate the different twilight periods as follow: nautical dawn, civil dawn, sunrise, sunset, civil dusk and nautical dusk. (Source: MEZÖFI et al. 2019) 
A pókok esetében az egyes szempárok különbözhetnek felépítésükben, érzékenységükben, de a különböző életmódú csoportok/fajok (például nappali vagy éjszakai vadászok) szemei között is megfigyelhetők különbségek (MUÑOZ-CUEVAS et al. 1998, YAMASHITA \& NAKAMURA 1999, BARTH 2002). A szemek érzékenysége a napszak függvényében változhat (MuÑOZ-CUEVAS et al. 1998), sőt, a szemekben lezajló folyamatoknak saját endogén cirkadián ritmusuk is lehet (KovoOR et al. 1999). Például az Araneus ventricosus (Araneidae) éjszakai faj esetében az elülső szemsor középszemei (AME) a sötét periódusban érzékenyebbek lesznek és konstans sötétségben is megtartják érzékenységükben a körülbelül 24-25 órás periódusú ritmusukat (YAMASHITA \& NAKAMURA 1999, YAMASHITA 2002).

A pókoknál a hímek általában aktívabbak/mobilisabbak a nőstényeknél, részben mivel a zsákmányszerzés mellett a nőstények felkutatása is az ő feladatuk (SALVESTRINI \& GASNIER 2001, SulLIVAN \& MORSE 2004, FRAMENAU 2005, FoEliX 2011). Bár a nőstények általában nagyobbak a hímeknél (HEAD 1995), a hímeknek sokszor relatíve hosszabbak a lábaik. E tulajdonságukat egy hipotézis szerint a számukra kedvezőbb nagyobb mobilitásra irányuló ivari szelekció eredményének köszönhetik (GASNIER et al. 2002, FRAMENAU 2005). A magasabb aktivitásukkal összefüggésben talajcsapdázással - mely elterjedt módszer a talajfelszíni pókközösségek mintázására és vizsgálatára (UETZ \& UNZICKER 1976) - általában nagyobb arányban gyüjthetők a hímek (például a Lycosidae, Thomisidae és Salticidae családoknál) (TOPPING \& SUNDERLAND 1992, PRÓSZYNSKI \& LUBIN 1993, FUJII 1997, BOGYA \& MARKÓ 1999). Kivételek eddig csak az ugrópókok köréből ismertek, ahol a nőstények bizonyultak az aktívabb ivarnak (TORK 2018, MEZÖFI et al. 2019). Az aktivitási szint mellett a két ivar napon belüli aktivitási mintázata is eltérö lehet (KRUMPALOVÁ \& TUF 2013, MEZÖFI et al. 2019). A pókoknál az aktívabb periódust általában magasabb metabolikus ráta is jellemzi (SCHMITZ 2004), továbbá a magasabb aktivitási szint összefügghet a gyorsabb életmenettel (RÁDAI et al. 2017) és a gyengébb kondícióval (INGLE et al. 2018). Az utóbbival összefüggésben az aktívan kereső vadászok esetében az éhezés következtében megnőhet az egyedek aktivitása (WALKER et al. 1999).

\section{Az aktivitási ritmus laboratóriumi vizsgálata}

Számos tanulmány született melyekben különböző pókfajok lokomotoros aktivitási ritmusát vizsgálták laboratóriumi körülmények között. ORTEGA-ESCOBAR (2002) Lycosa tarentula (Lycosidae) egyedeket vizsgált számítógéphez kapcsolt infravörös fotocellák segítségével, melyek a pókok mozgását érzékelve aktiválódtak. A pókok mozgási aktivitási ritmusát hat perces felbontásban értékelte, 1-es értéket kapott az egyed, ha aktív volt az adott időintervallumban és 0 értéket, ha nem. Teljes sötétségben (DD) vizsgálva az egyedek átlagosan 24,1 órás periódusú ,szabadon futó” ritmust mutattak. Az egyedeket LD (12:12) körülmények közé helyezve a pókok többsége éjszakai aktivitást mutatott, azonban konstans fényben (LL) vizsgálva aritmikus lett a mozgási aktivitásuk. ORTEGA-ESCOBAR (2002) a különböző szempárok letakarásával és szabadon hagyásával megállapította továbbá, hogy az elülső szemsor középszemeinek (AME), annak ellenére, hogy ennek a szempárnak van a legnagyobb szerepe az orientációban, nincs szerepe a ritmus szinkronizálásában. Azok az egyedek, melyeknél csak ez a szempár nem volt letakarva, LD körülmények között „fázis 
eltolódás” (phase shifting) lépett fel az aktivitási ritmusban, így „,szabadon futó” cirkadián ritmust mutattak. Ezzel szemben a többi három szempár (ALE, PME és PLE) mind képes volt a ritmus szinkronizálására.

SUTER (1993) számítógépre csatlakoztatott infravörös fototranzisztorok és infravörös diódák segítségével vizsgált üvegfiolákban tartott Frontinella pyramitela (Linyphiidae) és Argyrodes trigonum (Theridiidae) egyedeket. Megállapította, hogy nem minden egyes egyednél figyelhető meg cirkadián ritmus a lokomotoros aktivitásban, és, hogy részben magasabb frekvenciájú - rövidebb periódusidejü - (ultradián) endogén ritmusok is szerepet játszanak a mozgási aktivitási mintázatok kialakításában. SUTER \& BENSON (2014) csodáspók (Pisauridae) és farkaspók (Lycosidae) fajok adult és szubadult nőstény egyedeit vizsgálva arra a megállapításra jutott, hogy a legtöbb esetben az egyes egyedek nem követnek szigorúan nappali vagy éjszakai életmódot. A statisztikailag jelentős nokturnalitást vagy diurnalitást mutató egyedeknél/fajoknál is megfigyelhető akár komolyabb aktivitás a nyugalmi periódusban is. Az egyes pókok vizsgálatával megerősítették az ultradián periódusok jelenlétét.

A Cupiennius salei (Ctenidae), vagy a Parasteatoda (syn: Achaearanea) tepidariorum (Theridiidae) esetében is - melyek kedvelt modellfajok, fejlődésmenetük, biológiájuk régóta kutatott (BARTH 2008, MCGREGOR et al. 2008) - rendelkezésre állnak laboratóriumi megfigyeléseken alapuló adatok a fajok napi aktivitási mintázatáról (SEYFARTH 1980, SCHMITT et al. 1990, WOLF 2011). SCHMITT et al. (1990) aktográf (actograph) segítségével vizsgáltak három Cupiennius nembe tartozó fajt. A pókok aktivitását 72 órán keresztül mérték és 10 perces felbontásban értékelték ki. Azon kívül, hogy a fajok éjszakai aktivitást mutattak, megállapították, hogy a hímek átlagosan 3,5-12,7-szer aktívabbak a nőstényeknél és a $C$. coccineus, illetve $C$. getazi szimpatrikus fajpár esetében, a $C$. coccineus fajnak a relatív mozgási aktivitási minimuma a $C$. getazi faj abszolút aktivitási maximumával van átfedésben. Ez az aktivitási mintázatban megfigyelhető különbség feltehetően hozzájárul az említett két szimpatrikus faj reproduktív izolációjához.

TIETJEN \& CADY (2007) szubletális malathion (szerves foszforsav-észterek csoportjába tartozó rovarölő szer) dózis hatását vizsgálták többek között a Salticus scenicus (Salticidae) faj napi mozgási aktivitás mintázatára. Az állatok aktivitását egy videokamera segítségével rögzítették, mely 10 másodpercenként készített felvételeket az egyedekről. Az éjszakai felvételek infravörös LED megvilágítás mellett készültek, mivel ebben a tartományban ( 700 nm fölött) a kifejezetten jól látó ugrópókok szemei is teljesen érzéketlenek (YAMASHITA 2002, ZUREK et al. 2015). A vizsgálatban (TIETJEN \& CADY 2007) megállapították, hogy a malathion hatására hozzávetőleg egy órával korábbra tolódott a faj aktivitási csúcsa a kontroll egyedekéhez képest, rámutatva így a növényvédő szerek a hasznos ízeltlábú szervezetek napi aktivitási ritmusára gyakorolt esetleges mellékhatásaira. A növényvédő szerek az aktivitási szintre is negatív hatással lehetnek (BAATRUP \& BAYLEY 1993, PEKÁR \& BENES̆ 2008). BAATRUP \& BAYLEY (1993) például Pardosa amentata (Lycosidae) egyedek mozgási aktivitásának jelentős csökkenését figyelte meg szubletális cipermetrin (szintetikus piretroid rovarölő szer) kezelések hatására.

MOORE et al. (2016) a Cyclosa turbinata (Araneidae) faj lokomotoros aktivitásának vizsgálata közben tapasztalták a pókoknál ismert legrövidebb periódusidejü endogén „szabadon futó" ritmust (MAMMOLA et al. 2017). A normálisan éjszakai aktivitású faj egyedeit konstans sötétségbe (DD) helyezve, Aschoff harmadik szabályának megfelelően 24 óránál 
rövidebb, hozzávetőleg 19 óra körüli periódusidejü cirkadián ritmust eredményezett. Aschoff harmadik szabályának müködését számos más pókfajnál is megfigyelték (például ORTEGA et al. 1992, JONES et al. 2018, GARMANY et al. 2019). MoORE et al. (2016) megállapították továbbá, hogy a normálisan bimodális ritmus első csúcsát feltehetően a fény „hiánya" váltja ki, míg a második csúcs bizonyítja a ritmus endogén voltát, mivel normális körülmények között (LD) még a sötét szakaszban, a fény szakasz elött pár órával jelentkezik, és ez lehetett az, ami DD körülmények között is tovább „futott”, így alakítva ki a szokatlanul rövid periódusú ritmust.

Nemcsak a mozgási aktivitásban megjelenő cirkadián ritmus vizsgálatára van példa a pókoknál. JONES et al. (2011) azt a hipotézist tesztelték, miszerint ha bizonyos fajok a nap jól meghatározott szakaszában táplálkoznak, akkor kevésbé agresszívek (vagy inkább defenzívebbek) azokban a szakaszokban, amikor nem táplálkoznak, vagy nem keresik aktívan a forrásokat. Az éjszakai aktivitású Larinioides cornutus (Araneidae) faj egyedein az úgynevezett tetszhalál (thanatosis) antipredátor viselkedési választ vizsgálva megállapították, hogy az egyedeknél nappal tovább tart a tetszhalott állapot, mint éjjel. Konstans sötétségben és konstans fényben vizsgálva az egyedeket, szintén kimutatható volt, hogy ez az antipredátor viselkedési forma egyfajta cirkadián szabályzás alatt van. WATTS et al. (2015) Anelosimus studiosus (Theridiidae) egyedek merészségét vizsgálva megállapították, hogy a pókok a napnak abban az időszakában (este és az éjszaka első felében) a „legbátrabbak”, amikor a természetes élöhelyükön a legaktívabbak a potenciális zsákmányszervezetek. Eredményeikkel így rámutattak a viselkedésben jelentkező napon belüli plaszticitás (azaz a viselkedési mutatókban megnyilvánuló napi ritmusok) adaptív jelentőségére.

\section{A pókok aktivitási ritmusának megfigyelése természetes fotoperiódus mellett}

A szabadföldi megfigyelések nem feltétlenül támasztják alá a laboratóriumi körülmények között nyert megállapításokat, mivel a természetes környezet sokkal gazdagabb ciklikus stimulusokban. A cirkadián ritmusoknak a természeteshez minél közelebb álló körülmények között történő vizsgálata, az egyes ritmusok adaptív jelentőségének hitelesebb értelmezését teheti lehetővé (VANIN et al. 2012, KRONFELD-SCHOR et al. 2013, MENEGAZZI et al. 2013). Természetes körülmények között a szürkületi időszakot is figyelembe kell venni az aktivitási mintázat értékelésénél. A szürkület időszakát számíthatjuk a navigációs szürkület kezdetétől a napkeltéig és napnyugtától a navigációs szürkület végéig (ENSING et al. 2014). A nappalt viszont a polgári szürkület kezdete és vége határozza meg, mivel a fényintenzitás logaritmusának változása ezekben az időpontokban a leggyorsabb, így általában ezek az időpontok tekinthetők a biológiai rendszerek számára a fény „fel- és lekapcsolásának" (HUT et al. 2013). A navigációs szürkület alatt a nap $12^{\circ}$ és $6^{\circ}$ között, míg a polgári szürkület esetében a nap $6^{\circ}$ és $0^{\circ}$ között tartózkodik a horizont alatt (USNO 2018).

MARC (1991) videokamera segítségével rögzítette Anyphaena accentuata (Anyphaenidae, 1. ábra) egyedek aktivitási ritmusát természetes fényviszonyok és fotoperiódus mellett. Megállapította, hogy az A. accentuata éjszakai aktivitású, a napnyugta utáni három órás intervallumban a legaktívabb és aktív marad egészen addig, míg a fényintenzitás reggel el nem kezd növekedni. MEZÖFI et al. (2019) a rozsdás ugrópók (Carrhotus 
xanthogramma: Salticidae) és egy fürgekarolópók (Philodromus cespitum: Philodromidae) aktivitási mintázatait vizsgálták szintén természetes fény és fotoperiódus mellett. A $C$. xanthogramma esetében azt találták, hogy a faj szigorúan nappali aktivitású és mindkét ivar aktivitási csúcsa szinte percre pontosan megegyezik (3.a ábra). Az aktivitási ritmusuk kialakításában egyértelmüen a 24 órás periódusidejü komponensnek volt meghatározó szerepe (4.a ábra), de meglepő módon a nőstények aktívabbnak bizonyultak a hímeknél (5.a ábra). Ezzel szemben a $P h$. cespitum egyedek katemerális aktivitásúnak bizonyultak, azaz a nap minden szakaszában mutattak aktivitást. A két ivar aktivitási mintázata eltért, a nőstények éjszaka, közvetlenül a navigációs szürkület előtt voltak a legaktívabbak, míg a hímek átlagos aktivitási csúcsa reggelre esett (3.b ábra). Az utóbbi faj katemerális aktivitásával összefüggésben számos ultradián komponens volt detektálható az aktivitási ritmusban, különösen a nőstények esetében, ahol a relatíve erös 12 órás periódusidejü komponens miatt bimodálisnak bizonyult az említett ivar aktivitása (4.b és 5.b ábra).
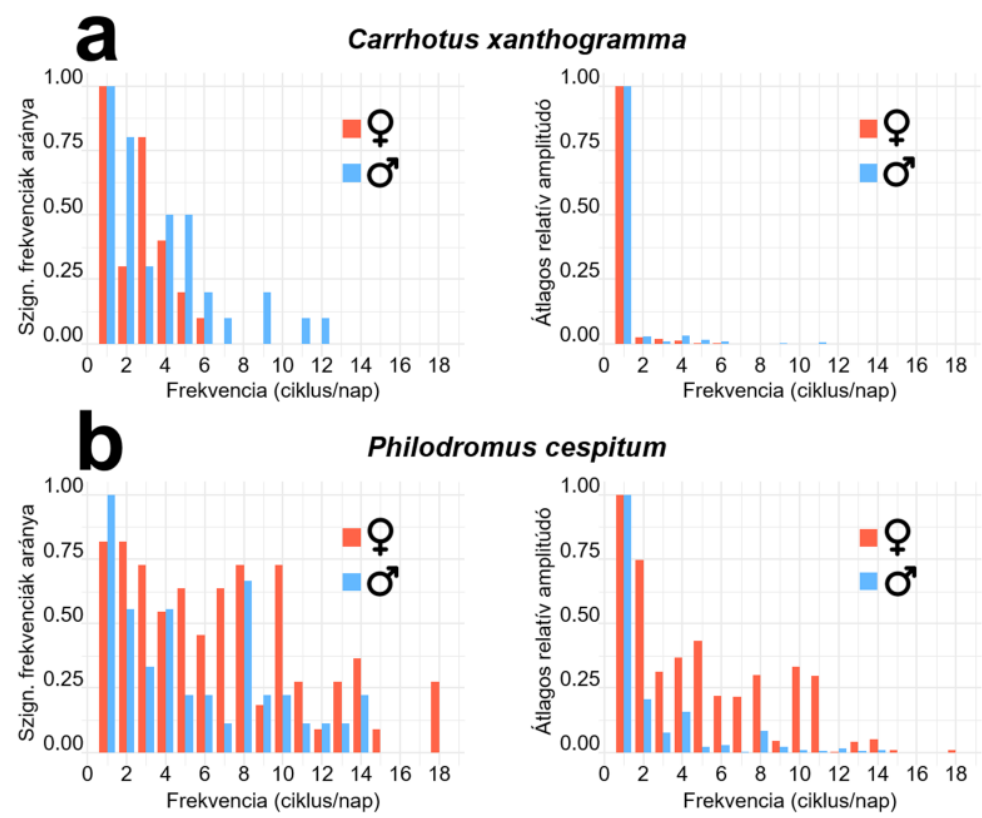

4. ábra. Carrhotus xanthogramma (Salticidae) (a) és Philodromus cespitum (Philodromidae) (b) egyedek idősorainak (72 óra hossz) Fourier-analízise. Baloldalt a szignifikáns ( $\alpha<0,01$ szinten detektált) frekvenciák populáción belüli arányát, míg jobboldalt a detektált frekvenciák átlagos relatív amp-

litúdóit tüntettük fel a legnagyobb átlagértékhez normalizálva. (Forrás: MEZÖFI et al. 2019)

Figure 4. Results of the Fourier analysis of the time series ( $72 \mathrm{~h} \mathrm{long)} \mathrm{recorded} \mathrm{for} \mathrm{Carrhotus} \mathrm{xanthogramma}$ (Salticidae) (a) and Philodromus cespitum (Philodromidae) (b). On the left, we show the probabilities of the appearance of significant peaks in a given number of cycles per day. The probabilities are computed as the ratio between the number of individuals exhibiting a spectral peak (detected at $\alpha<0.01$ level) in a given cycle and the total number of females and males studied. On the right, we show the individual means of the relative powers of the significant spectral peaks for the female and male spiders, in terms of the number of daily cycles. The plotted values are normalized relative to the largest mean value. (Source: MEZŐFI et al. 2019) 

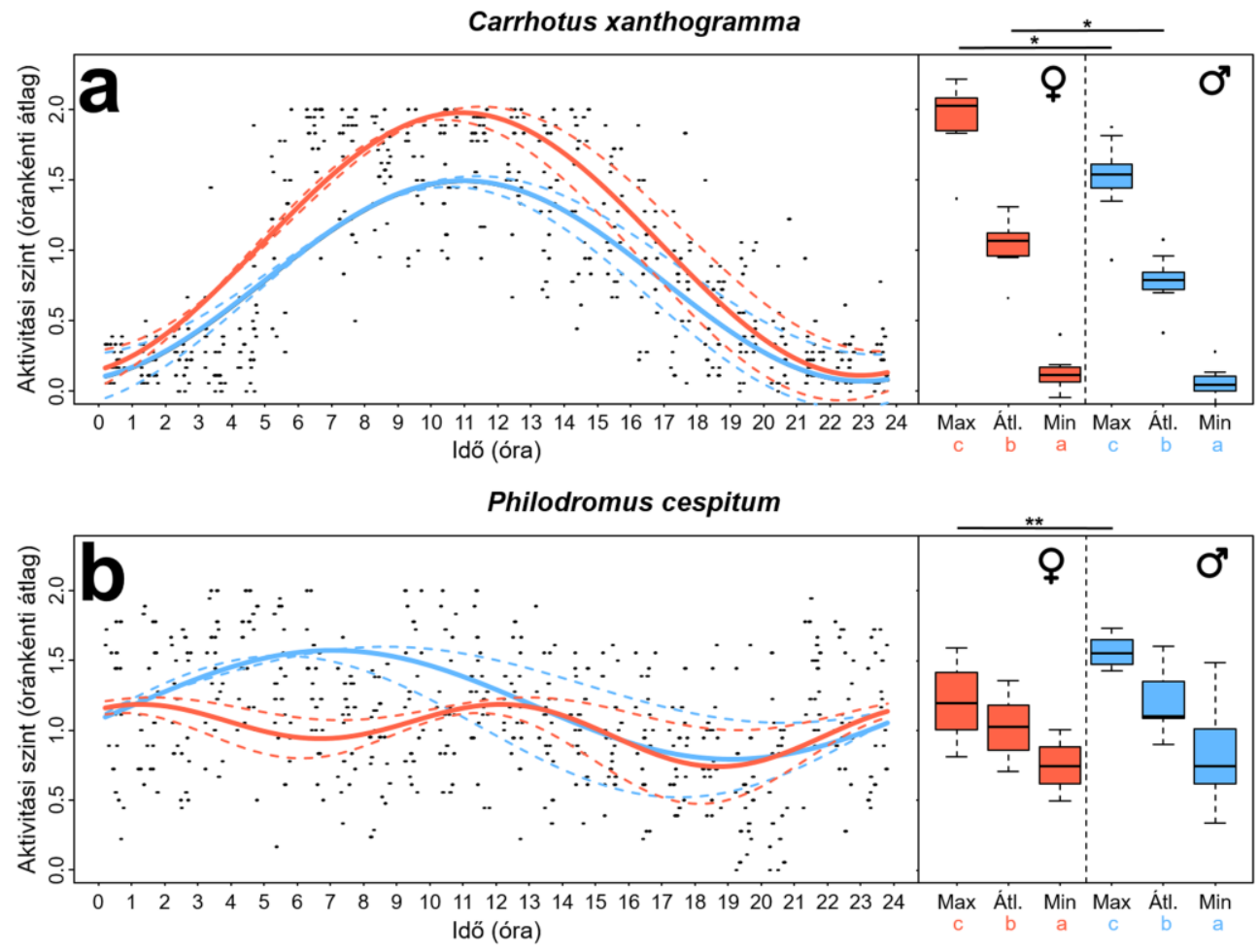

5. ábra. Carrhotus xanthogramma (Salticidae) (a) és Philodromus cespitum (Philodromidae) (b) egyedek ivarspecifikus napi (és 12 órás) lokomotoros aktivitási ritmusa. A bal oldali panelen a fix 24 órás periódusidővel illesztett koszinusz görbék láthatók. A pontok az egyes egyedek óránkénti átlagos aktivitási szintjét jelölik. A szaggatott vonalak a 95\%-os konfidencia intervallumát mutatják a görbéknek. A jobb panelen láthatók az ivarspecifikus különbségek az egyedileg illesztett görbék különböző fázisai által kijelölt aktivitási szintekben: az aktivitási szint a görbék maximumában (Max), minimumában (Min) és az átlagos aktivitási szintek (Átl.). A különböző betük szignifikáns különbséget $(P<0,05)$ jeleznek az adott faj nőstényein és hímjein belül, míg a csillagok $(*=P<0,05, * *=P<$ 0,01) az ivarok közötti különbséget mutatják. (Forrás: MEzöFI et al. 2019)

Figure 5. Daily (and $12 \mathrm{~h}$ ) locomotor activity rhythms recorded for Carrhotus xanthogramma (Salticidae) (a) and Philodromus cespitum (Philodromidae) (b). In the left panel cosine-fitted curves based on the model parameters obtained using a fixed 24-h period are shown. Each dot is the hourly average activity level (jittered) of one individual. Dashed lines indicate the $95 \%$ confidence intervals of the sex-specific fitted curves. Sex-related differences in the activity levels at different phases of cosine curve are shown in the right panel. The activity levels at the maximum (Max) and at the minimum (Min) of the individually fitted cosine curves and the mean levels of activity (Átl.). Different letters indicate significant differences $(P<0.05)$ within males and females of a species

while the asterisks indicate significant differences $(*=P<0.05, * *=P<0.01)$ between the sexes. (Source: MEZÖFI et al. 2019)

Számos kifejezetten szabadföldi megfigyelést is végeztek a pókok napon belüli aktivitásának meghatározására. PFANNENSTIEL \& YEARGAN (2002) például Helicoverpa zea (Noctuidae) tojásokat helyeztek ki kukorica és szójanövényekre, majd három óránként ellenőrizték, hogy milyen szervezetek táplálkoznak a tojásokkal. Ezzel a módszerrel állapítot- 
ták meg, hogy a Clubiona abbotii (Clubionidae) kalitpókfaj csak éjjel zsákmányolja a tojásokat. WARD \& LUBIN (1992) vizes élőhelyeken figyelte meg az ott élő keresztespókfélék (Araneidae) éjszakai aktivitását. Megállapították, hogy ősszel a kisebb méretű pókok jellemzően a napnyugta körüli időszakban készítik hálóikat, amikor a kisebb szúnyogalkatú zsákmányok rajzanak. A nagyobb pókok ezzel szemben az éjszaka folyamán később szövik (nagyobb) hálóikat, amikor a nagyobb méretü rovarok (például éjjeli lepkék) repülnek. WARD \& LUBIN (1992) szerint a nagyobb pókok nem a nagyobb méretü éjjeli lepkék miatt éjszakáznak, hanem mert az esti szürkületben a nagyobb pókok könnyebben áldozatul eshetnek a ragadozóiknak, mint teljes sötétségben. NøRGAARD et al. (2006) infravörös fénysorompókat helyeztek ki a Namib-sivatagban élö Leucorchestris arenicola (Sparassidae) vadászpókfaj aktivitásának tanulmányozásához. Megállapították, hogy a faj szigorúan éjszaka aktív és a legsötétebb éjszakákon, azaz újholdkor legmagasabb az aktivitása. Talajcsapdák kihelyezésével és fogásuk rendszeres időközönként történő ellenőrzésével jól nyomon követhető a talajfelszíni ízeltlábúak napszakos aktivitása. Az ilyen mintagyüjtést megkönnyítendö, többféle automatizált talajcsapdát (time-sorting pitfall trap) is kifejlesztettek (Blumberg \& CROSSLEy 1988, BuCHHOlz 2009). KRUMPALOVÁ \& TuF (2013) egy csehországi ártéri erdőben és környékén tavaszi és őszi felvételezéseket végeztek talajcsapdákkal. 100 csapdát helyeztek ki és több napon keresztül három óránként ellenőrizték azok tartalmát. Ebben az esetben úgy találták, hogy a vizsgált területen a talajszinten élö pókfajok körében a nappali aktivitás gyakoribb, mint az éjszakai. Az 5 mm-nél kisebb testmérettel rendelkező fajok (például Linyphiidae család tagjai) késő éjszaka, illetve reggel, míg az 5 mm-nél nagyobb testmérettel rendelkező fajok (például Lycosidae család fajai) délután, illetve este voltak aktívak. Részben a talajfelszín hőmérsékletével lehet összefüggésben az aktivitási mintázatbeli eltérés, ugyanis a nagyobb pókok a nap melegebb időszakában voltak aktívak. Valószínủleg ez teszi lehetővé a különböző testmérettel rendelkező fajok koegzisztenciáját a talajfelszín pókegyüttesében. Tehát a testméret a cirkadián aktivitást jelentősen befolyásoló faktor lehet (KRUMPALOVÁ \& TUF 2013). CHAPMAN \& ARMSTRONG (1997) automatizált talajcsapdákkal követték nyomon fejes káposzta parcellák talajfelszíni pókjainak napszakos aktivitását. Az egyik parcellát gyommentesen tartották, a másiknál here alávetést alkalmaztak. Azt találták, hogy az Erigone (Linyphiidae) nem egyedei a gyommentesen tartott parcellában éjszaka és reggel aktívak, míg a plusz takarónövényzettel borított parcellában napközben mutatták a legnagyobb aktivitást. A vizsgálat rámutat a habitat, illetve a habitat hordozta tulajdonságok esetleges aktivitást módosító hatására. A főleg éjszaka aktív pókok a plusz takarónövényzettel borított parcellában feltehetően az ott uralkodó párásabb mikroklíma és alacsonyabb talajhőmérséklet miatt tudtak nappal is aktívak lenni. Számos tanulmányt lehetne még sorolni (DONDALE et al. 1972, ALDERWEIRELDT 1994, FUJII 1997, MARSHALL et al. 2002, LUNDGREN et al. 2009, KRÓL et al. 2018) melyekben szintén talajcsapdák segítségével vizsgálták a talajszinten élő pókfajok napi aktivitási ritmusát. Sokkal kevesebben foglalkoztak a különböző fás növények lombozatán élő pókfajok aktivitási ritmusának szabadföldi megfigyelésével. Almaültetvények lombkoronaszintjén előforduló pókfajok napszak szerinti aktivitását BROWN et al. (2003) vizsgálták részletesebben. Egy észak-virginiai (USA) almaültetvényben, óránként végzett kopogtatásos mintavételezések alapján megállapították, hogy az ott előforduló jegyespókoknak (Anyphaenidae) átlagosan 01:00 \pm 3 órakor, a fürgekarolópókoknak (Philodromidae) 23:00 \pm 5 órakor, és a

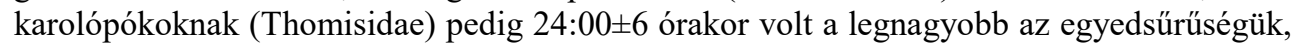
tehát ezekben az órákban lehet az aktivitási csúcsuk is. Megjegyzendő, hogy a lombozat 
rázásával vagy a vázágak ütögetésével bizonyos esetekben az éjjeli és nappali fajok egyedei egyaránt hatékonyan gyüjthetők, így az ilyenfajta mintavételezésből nem mindig lehet messzemenő következtetéseket levonni a gyüjtött faj napszakos aktivitására (COSTELLO \& DAANE 2005).

\section{A biológiai ritmusok értékelése}

A cirkadián fiziológia területén végzett adatelemzésnek a feladata többnyire a cirkadián ritmicitás azonosítása olyan adathalmaz esetén, mely számos ritmikus és nem ritmikus komponenst tartalmaz. Mivel az adatpontok időben egymást követő megfigyelésekre vonatkoznak ezért az adatkészletet gyakran ,idősornak” is nevezik (REFINETTI et al. 2007, REFINETTI 2016).

Általánosságban különbséget tehetünk „,időtartományban” (time domain) és „,frekvenciatartományban” (frequency domain) történő elemzés között. Míg az „időtartományban” alkalmazott módszerek magában az idősorban keresik a szabályszerüségeket, addig a „frekvenciatartományban" alkalmazott módszerek az idősorokat összetett oszcillációs folyamatokként kezelik. „Időtartományban” elemezve az idősorokat megállapíthatjuk, hogy bizonyos folyamatokban milyen időközönként történik változás, míg „frekvenciatartományban” vizsgálódva (például Fourier-analízist végezve), a különböző periódussal rendelkező komponenseit is azonosítani tudjuk az idősornak (REFINETTI 2016).

Az elemzés első lépéseként az idősorokat vizuálisan vizsgáljuk meg, azokat valamilyen grafikai eszköz/módszer segítségével láthatóvá téve. Az adatok ilyen módon történő megtekintése segítséget nyújt a pontosabb numerikus elemzés eljárásának kiválasztásához (REFINETTI et al. 2007). Idősoraink tulajdonságait megvizsgálhatjuk az idősorokat derékszögü koordináta rendszerben ábrázolva (ahol az x tengelyen az időt, míg az y tengelyen a mért változóinkat tüntetjük fel). Egy másik népszerű módszer az idősorok ábrázolására az úgynevezett aktogram (actogram), mely tulajdonképpen az egy napos grafikonok egymás utáni napok sorrendjében történő egymás alá illesztéséből áll. Kiegészítő jelleggel a hoszszabb adatsorok esetén egy tetszőleges kisebb periódusra történő akkumulálása (vagy kivonatolása) az adatoknak (2. ábra) is segítheti különböző ritmikusságok jobb felismerését. Ha az idősorunk nem elég tiszta, akkor megfelelő szüréssel - például mozgó átlag illesztésével - láthatóbbá tehetjük az adott ritmust. A jól kivehető ritmikusságok ellenére is, komolyabb matematikai analízis szükséges az egyes ritmikusságok objektív mutatójának megállapításához (REFINETTI et al. 2007, CORNELISSEN 2014, REFINETTI 2016).

A ritmikus mintázat négy paraméterrel jellemezhető, melyek a következők: periódus, amplitúdó, fázis és átlagos szint (6. ábra) (REFINETTI et al. 2007, REFINETTI 2016). A periódus az egymást követő csúcsok közötti távolság, vagyis egy hullám időtartama. Ha a hullám időtartamának (másodpercben) reciprokát vesszük, akkor megkapjuk a frekvenciát. Az amplitúdó a hullám oszcillációjának fele. A fázis (vagy „fázisszög”) egy relatív kifejezés, a referenciaszög (referenciapont) és az oszcilláció közötti relatív (szög)elmozdulás. A cirkadián ritmusok esetében a ritmus fázisát gyakran a környezeti fény-sötétség ciklussal kapcsolatban határozzák meg, órában kifejezve. Az átlagos szint pedig az, ami körül a hullám oszcillál (REFINETTI et al. 2007, REFINETTI 2016). 


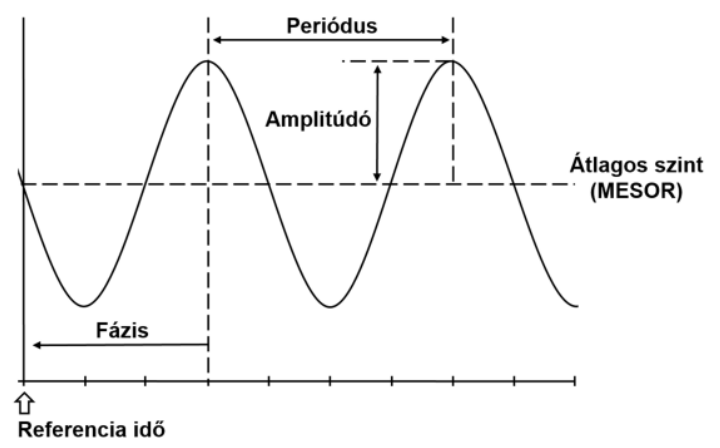

6. ábra. Az oszcillációs folyamatok paraméterei: periódus, amplitúdó, fázis és MESOR.

Figure 6. Parameters of oscillatory processes: period, amplitude, phase and MESOR.

A cirkadián ritmusok analizálása során további két paramétert is meg kell vizsgálnunk, úgymint a hullámformát (mely lehet például szinuszos), vagy a ritmus robosztusságát/kiválóságát. A hullámformát például a harmonikus tartalom határozhatja meg, míg a robosztusság/kiválóság például a jel-zaj aránytól és a ritmus stacionaritásától függ. A ritmikus paraméterek egzakt matematikai analízise feltételezi az idősorok stacionaritását, azaz a várható érték, variancia és autokorrelációs koefficiens időbeni hozzávetőleges állandóságát. Mivel a biológiai ritmusok nem szigorúan stacionáriusak, ezért általában csak hozzávetőlegesen elemezhetők (REFINETTI et al. 2007, REFINETTI 2016).

A biológiai ritmusok különböző paramétereinek illetve tulajdonságainak becslésére/ elemzésére számos grafikai és matematikai módszer létezik (lásd például: REFINETTI et al. 2007, REFINETTI 2016). A továbbiakban ezek közül csak a fontosabb eljárásokat ismertetjük.

(1) Cirkuláris statisztika: Abban az esetben, amikor az egyetlen gyüjthető adat az idő (amikor bizonyos események történnek), nagyon hasznosak lehetnek a cirkuláris statisztika tárgykörébe tartozó módszerek (REFINETTI et al. 2007, PEWSEY et al. 2013). Mivel ciklikus folyamatok elemzéséről van szó, könnyen belátható, hogy ezeket a folyamatokat akár egy kör mentén (ahol a 360 24 órának felel meg) is ábrázolhatjuk (3. ábra). Az idősorunkat egy körfolyamatként, elemeit pedig egységvektorokként kezeljük. Az egységvektoroknak kiszámíthatjuk az átlagvektorát, mely szöge (iránya) fejezi ki a cirkuláris átlagot. A cirkuláris átlagot (circular mean), vagy átlagos irányt unimodális eloszlások esetén aktivitási csúcsként is szokták interpretálni (MEZÖFI et al. 2019). Kiszámítható az átlagvektor hossza, melyet átlagos rezultáns (eredő) hossznak (mean resultant lenght) neveznek. A rezultáns hossz 0 és 1 közötti értéket vehet fel és minél közelebb van az érték az 1-hez, a vektor annál erösebb aktivitási csúcsot jelez az adott időpontban, míg a 0-hoz közeli értékek katemerális aktivitási mintázatra utalnak (RANGANATHAN et al. 2010). A cirkuláris mintánk körön való egyenletes eloszlását különböző próbákkal tesztelhetjük. Ilyen próbák például a Rayleigh teszt (ellenhipotézise valamilyen unimodális eloszlás) vagy a Rao's spacing és Watson's $U^{2}$ tesztek (ellenhipotézisük az összes nem egyenletes eloszlást magában foglalja). Két cirkuláris mintát összehasonlíthatunk például a Watson's two-sample $U^{2}$ teszttel, mellyel megállapítható, hogy a két mintánk származhat-e ugyanabból az alapsokaságból, azaz egyezik-e az 
eloszlásuk. Az említett próbák folytonos változókat igényelnek, így ha csoportosított adatkészlettel (például a napot 12 részre bontva) dolgozunk, más próbát, vagy az említett próbák módosított változatát kell alkalmaznunk (PEWSEY et al. 2013). A cirkuláris statisztikai eljárások hátránya, hogy sem az amplitúdó, sem a ritmusra jellemző periódus/periódusok hossza nem becsülhető velük (REFINETTI et al. 2007).

(2) Varianciaanalízis (ANOVA): Habár a módszer önmagában semmit nem mond a periodicitásról, segítségével egy zajos ritmus megkülönböztethető a random oszcillációtól, ha a ritmus periódusa legalább hozzávetölegesen ismert (MINORS \& WATERHOUSE 1988, REFINETTI et al. 2007).

(3) Fourier-analizis: A spektrális analízisnek is nevezett módszer azon a felismerésen alapszik, miszerint bármilyen idősor, formájától és szabályosságától függetlenül, különböző frekvenciájú szinusz és koszinusz hullámok sorozatával írható le. Így, ha egy idősor Fourier-analízise során egy jelentős frekvencia komponens mutatható ki a cirkadián tartományban, abból arra következtethetünk, hogy a vizsgált folyamat cirkadián ritmikusságot mutat. Amellett, hogy a módszerrel meghatározható a vizsgált ritmust jellemző periódus/periódusok, a Fourier-analízis során készített periodogram segítségével láthatóvá tehető az egyes frekvenciák relatív amplitúdója vagy spektrális energiája is (REFINETTI et al. 2007, 4. ábra). A Fourier analízisen alapuló módszerek számos változatát elterjedten használják különböző ritmikus folyamatok periodicitásának vizsgálatakor. A módszer hátránya, hogy általában csak equidisztáns megfigyelések esetén alkalmazható és az idősor hossza többszöröse kell legyen az alapperiódusénak (MINORS \& WATERHOUSE 1988, REFINETTI 1993, FORREST \& SUTER 1994, LEISE 2013, AMARIEI et al. 2014).

(4) Cosinor módszer: A módszer abból áll, hogy az adatainkra egy ismert periódussal rendelkező (például 24 óra + esetleges hozzáadott harmonikusok) koszinusz görbét tartalmazó modellt illesztünk (lineáris regresszióval, a legkisebb négyzetek módszerével) a ritmus mintázatának becslése céljából. Így kiszűrhető a zaj és láthatóvá tehető a zaj által elfedett alapritmus (5. ábra). Ezzel a módszerrel meghatározható például a ritmus MESOR-ja (Midline Estimating Statistic Of Rhythm), mely tekinthető az átlagos szintnek, de nem feltétlenül azonos az adatpontjaink számtani közepével. Kiszámítható továbbá az oszcilláció amplitúdója és a fix referenciaidőhöz viszonyított maximum fázisa [azaz az akrofázis (acrophase), az illesztett görbe csúcsának fázisa], mely utóbbit szintén szoktak aktivitási csúcsként interpretálni. Ha az illesztett görbe amplitúdója statisztikailag nagyobb, mint nulla, akkor az idősor 24 órás ritmicitást mutat. A módszer nem equidisztáns megfigyelések, illetve rövid (akár egy periódus hosszúságú), vagy kivonatolt idősorok (educed rhythms) esetén is jól alkalmazható (MINORS \& WATERHOUSE 1988, REFINETTI et al. 2007, FERNÁNDEZ et al. 2009, CORNELISSEN 2014). A módszert és azok egyes változatait (például koszinusz görbék különböző transzformáltjainak illesztését) széleskörüen alkalmazzák különböző biológiai ritmusok elemzése során (HALBERG 1969, NAITOH et al. 1985, CuGINI 1993, MARLER et al. 2006). A módszer hátránya, hogy korlátozott feltételek között alkalmazható. Ha az adott feltételek sérülnek (például a regressziós diagnosztika során számolt hibatagok nem normális eloszlásúak, nem függetlenek, vagy varianciájuk nem homogén, stb.) akkor a modellünkből számolt paraméterek tévesek lehetnek, bár még így is hasznos lehet a becslésük (DE PRINS \& WALdURA 1993, FERNÁNDEZ et al. 2009, CORNELISSEN 2014). Ha a ritmus periódusa nem ismert, a mai számítógépes kapacitás lehetővé teszi a hagyományos Cosinor módszer megkerülését és a görbe iterációs illesztését (és minden para- 
méter becslését), azonban utóbbi nemlineáris eljárás nem mindig alkalmazható megfelelően és még szigorúbbak a feltételei, mint a hagyományos módszernek (ALONSO \& FERNÁNDEZ 2001, REFINETTI et al. 2007, CORNELISSEN 2014).

(5) További módszerek: Attól függően, hogy milyen természetűek az adataink, számos más módszerből is válogathatunk az idősorunk ritmicitásának megállapításához. Ezekkel a különböző matematikai hátterü eljárásokkal meghatározható a ritmust jellemző fő periódus/periódusok. A periodicitás egészen egyszerü módon is becsülhető (REFINETTI 1991), de a periódusok meghatározására alkalmasabb az Enright periodogram (mely $\chi^{2}$ eloszlást alapul vevő változatát chi négyzet periodogrammnak is nevezik) vagy a Lomb-Scargle periodogram. Az előbbi módszer equidisztáns megfigyelések esetén alkalmazható, míg utóbbi lehetővé teszi szabálytalan időközönként gyüjtött adatok vagy hiányos idősorok elemzését (REFINETTI 1993, RUF 1999, REFINETTI et al. 2007).

\section{Konklúzió}

A dolgozatot átolvasva láthatjuk, hogy a pókok rendkívül sokféle módon alkalmazkodtak a környezetükhöz. Bár az elmúlt évtizedekben tetemes mennyiségü ismeretanyaggal gyarapodtunk a napszakos aktivitásukat, illetve a biológiai ritmusaikat illetőleg, e tekintetben még számos faj biológiája ismeretlen és sok a megválaszolásra váró kérdés. Az agrárterületeken előforduló számos faj közül többnek is szerepe lehet bizonyos kártevők populációinak gyérítésében, így a megörző biológiai védekezésben is (MEZŐFI et al. 2020). Ha ezeknek a fajoknak jobban ismernénk a napszakos aktivitását, nemcsak teljesebb képet kapnánk arról, hogy mivel táplálkozhatnak, hanem a növényvédelmi kezelések idejének helyes megválasztásával jobban kímélhetnénk ezeket a peszticidektől is. Mégis, agrobiont pókfajok cirkadián aktivitásáról meglehetősen kevés ismeret áll rendelkezésünkre. Ugyancsak kevéssé ismert, hogy a különböző antropogén eredetü behatások, mint a különböző peszticidek használata vagy a fényszennyezés, milyen hatással vannak a pókok aktivitási ritmusaira. A 24 óránál rövidebb periódusú (ultradián) komponenseknek feltehetően van (vagy valaha volt) valamilyen adaptív jelentősége. Bár számos faj aktivitási ritmusában kimutatták ezen komponensek jelenlétét, azok funkciója mindmáig ismeretlen. A pókok ivari dimorfizmusával és az ezt kialakító szelekciós erőkkel számos tanulmány foglalkozik, de a biológiai ritmusaikban megjelenő ivarspecifikus különbségekkel annál kevesebb. Nyitott kérdés, hogy egyes fajok esetében miért követnek az ivarok különböző napirendet, de az sem teljesen tisztázott, hogy milyen adaptív előnyökkel jár az egyik vagy másik ivar fokozott aktivitása. Alig ismert továbbá, hogy a nem szigorúan nappali vagy éjszakai fajoknál mely tényezők lehetnek azok, melyek befolyásolják az aktivitás idejét. Számos további kérdés vár még válaszra, de az itt felvetett problémákkal bizonyosan számos tanulmány fog foglalkozni az elkövetkezendő években.

Köszönetnyilvánítás. Munkámat az NKFI (K112743) és az Innovációs és Technológiai Minisztérium ÚNKP-19-3-III kódszámú Új Nemzeti Kiválóság Programja támogatta. 


\section{Irodalomjegyzék}

ALDERWEIRELDT, M. (1994): Day/night activity rhythms of spiders occurring in crop-rotated fields. European Journal of Soil Biology 30: 55-61.

Alonso, I. \& FeRnÁndeZ, J. R. (2001): Nonlinear estimation and statistical testing of periods in nonsinusoidal longitudinal time series with unequidistant observations. Chronobiology International 18: 285-308. https://doi.org/10.1081/CBI-100103192

Amariei, C., Tomita, M. \& Murray, D. B. (2014): Quantifying periodicity in omics data. Frontiers in Cell and Developmental Biology 2: 40. https://doi.org/10.3389/fcell.2014.00040

Aschoff, J. (1960): Exogenous and endogenous components in circadian rhythms. Cold Spring Harbor Symposia on Quantitative Biology 25: 11-28. https://doi.org/10.1101/SQB.1960.025.01.004

AsCHOFF, J. (1966): Circadian activity pattern with two peaks. Ecology 47: 657-662. https://doi.org/10.2307/1933949

Aschoff, J. (1979): Circadian rhythms: influences of internal and external factors on the period measured in constant conditions. Zeitschrift für Tierpsychologie 49: 225-249. https://doi.org/10.1111/j.1439-0310.1979.tb00290.x

Aschoff, J. (1981): A survey on biological rhythms. In: Aschoff, J. (ed.): Biological Rhythms. Plenum Press, New York, pp. 3-10. https://doi.org/10.1007/978-1-4615-6552-9_1

AschOFF, J. (1989): Temporal orientation: circadian clocks in animals and humans. Animal Behaviour 37: 881-896. https://doi.org/10.1016/0003-3472(89)90132-2

BAATRUP, E. \& BAYLEY, M. (1993): Effects of the pyrethroid insecticide cypermethrin on the locomotor activity of the wolf spider Pardosa amentata: quantitative analysis employing computerautomated video tracking. Ecotoxicology and Environmental Safety 26: 138-152. https://doi.org/10.1006/eesa.1993.1046

BARTH, F. G. (2002): A spider's world: senses and behavior. Springer-Verlag, Berlin, Heidelberg, 394 pp.

BARTH, F. G. (2008): Cupiennius (Araneae, Ctenidae): Biology and sensory ecology of a model spider. In: Weissenhofer, A., Huber, W., Mayer, V., Pamperl, S., Weber, A. \& Aubrecht, G. (eds): Natural and Cultural History of the Golfo Dulce Region, Costa Rica. Oberösterreichische Landesmuseum, Linz, Stapfia 88, pp. 211-224.

Batista, G. E. A. P. A., Hao, Y., Keogh, E. \& Mafra-Neto, A. (2011): Towards automatic classification on flying insects using inexpensive sensors. In: Machine Learning and Applications and Workshops (ICMLA). 10th. International Conference on Machine Learning and Applications. Honolulu, Hawaii, 2011. December 18-21. 1: 364-369. https://doi.org/10.1109/ICMLA.2011.145

BeAulÉ, C. (2009): Aschoff's Rules. In: Binder, M. D., Hirokawa, N. \& WindHorst, U. (eds.): Encyclopedia of Neuroscience. Springer-Verlag, Berlin, Heidelberg, pp. 190-193. https://doi.org/10.1007/978-3-540-29678-2_383

Bloch, G., Barnes, B. M., Gerkema, M. P. \& Helm, B. (2013): Animal activity around the clock with no overt circadian rhythms: patterns, mechanisms and adaptive value. Proceedings of the Royal Society B 280: 20130019. https://doi.org/10.1098/rspb.2013.0019

Blumberg, A. Y. \& Crossley JR, D. A. (1988): Diurnal activity of soil-surface arthropods in agroecosystems: Design for an inexpensive time-sorting pitfall trap. Agriculture, Ecosystems \& Environment 20: 159-164. https://doi.org/10.1016/0167-8809(88)90107-7 
BogYA, S. \& MARKó, V. (1999): Effect of pest management systems on ground-dwelling spider assemblages in an apple orchard in Hungary. Agriculture, Ecosystems \& Environment 73: 7-18. https://doi.org/10.1016/S0167-8809(99)00010-9

Brown, M. W., Schmitt, J. J. \& Abraham, B. J. (2003): Seasonal and diurnal dynamics of spiders (Araneae) in West Virginia orchards and the effect of orchard management on spider communities. Environmental Entomology 32: 830-839. https://doi.org/10.1603/0046-225X-32.4.830

Buchнolz, S. (2009): Design of a time-sorting pitfall trap for surface-active arthropods. Entomologia Experimentalis et Applicata 133: 100-103. https://doi.org/10.1111/j.1570-7458.2009.00902.x

Chapman, P. A. \& Armstrong, G. (1997): Design and use of a time-sorting pitfall trap for predatory arthropods. Agriculture, Ecosystems \& Environment 65: 15-21. https://doi.org/10.1016/S01678809(97)00055-8

Cloudsley-Thompson, J. L. (1981): A comparison of rhythmic locomotory activity in tropical forest Arthropoda with that in desert species. Journal of Arid Environments 4: 327-334. https://doi.org/10.1016/S0140-1963(18)31478-2

Cloudsley-Thompson, J. L. (1987): The biorhythms of spiders. In: NenTwiG, W. (ed.): Ecophysiology of Spiders. Springer-Verlag, Berlin, Heidelberg, pp. 371-379. https://doi.org/10.1007/978-3642-71552-5_28

Cloudsley-Thompson, J. L. (2000): Biological rhythms in Arachnida (excluding Acari). Memorie della Societa Entomologica Italiana 78: 251-273.

Cornelissen, G. (2014): Cosinor-based rhythmometry. Theoretical Biology and Medical Modelling 11: 16. https://doi.org/10.1186/1742-4682-11-16

Costello, M. J. \& DAane, K. M. (2005): Day vs. night sampling for spiders in grape vineyards. Journal of Arachnology 33: 25-32. https://doi.org/10.1636/H02-52

CuginI, P. (1993): Chronobiology: principles and methods. Annali dell'Istituto Superiore di Sanità 29: 483-500.

DANKs, H. V. (2003): Studying insect photoperiodism and rhythmicity: components, approaches and lessons. European Journal of Entomology 100: 209-221. https://doi.org/10.14411/eje.2003.036

De Prins, J. \& WALduRA, J. (1993): Sightseeing around the single cosinor. Chronobiology International 10: 395-400. https://doi.org/10.3109/07420529309064493

Dondale, C. D., Redner, J. H. \& Semple, R. B. (1972): Diel activity periodicities in meadow arthropods. Canadian Journal of Zoology 50: 1155-1163. https://doi.org/10.1139/z72-154

Ensing, E. P., Ciuti, S., DE Wijs, F. A. L. M., Lentferink, D. H., ten Hoedt, A., Boyce, M. S. \& Hut, R. A. (2014): GPS based daily activity patterns in European red deer and North American elk (Cervus elaphus): indication for a weak circadian clock in ungulates. PLOS ONE 9: e106997. https://doi.org/10.1371/journal.pone.0106997

FernándeZ, J. R., HermidA, R. C. \& Mojón, A. (2009): Chronobiological analysis techniques: application to blood pressure. Philosophical Transactions of the Royal Society A: Mathematical, Physical and Engineering Sciences 367: 431-445. https://doi.org/10.1098/rsta.2008.0231

FoElIX, R. F. (2011): Biology of Spiders, $3^{\text {rd }}$ Edition. Oxford University Press, New York, 419 pp.

ForRest, T. G. \& SUTER, R. B. (1994): The discrete Fourier transform (DFT) in behavioural analysis. Journal of Theoretical Biology 166: 419-429. https://doi.org/10.1006/jtbi.1994.1037

FRAMENAU, V. W. (2005): Gender specific differences in activity and home range reflect morphological dimorphism in wolf spiders (Araneae, Lycosidae). Journal of Arachnology 33: 334-346. https://doi.org/10.1636/04-57.1 
FuJII, Y. (1997): Ecological studies on wolf spiders (Araneae: Lycosidae) in a Northwest area of Kanto plain, central Japan: diel activity and habitat preference observed by pitfall trapping. Acta Arachnologica 46: 5-18. https://doi.org/10.2476/asjaa.46.5

Garmany, M., Moore, D. \& Jones, T. C. (2019): Diel and circadian rhythms of locomotor activity in male Parasteatoda tepidariorum (Araneae: Theridiidae). Journal of Arachnology 47: 310-316. https://doi.org/10.1636/0161-8202-47.3.310

Gasnier, T. R., De Azevedo, C. S., Torres-Sanchez, M. P. \& HöFer, H. (2002): Adult size of eight hunting spider species in central Amazonia: temporal variations and sexual dimorphisms. Journal of Arachnology 30: 146-154. https://doi.org/10.1636/0161-8202(2002)030[0146:ASOEHS]2.0.CO;2

Goto, S. G. \& TAKEKATA, H. (2015): Circatidal rhythm and the veiled clockwork. Current Opinion in Insect Science 7: 92-97. https://doi.org/10.1016/j.cois.2014.12.004

Halberg, F. (1969): Chronobiology. Annual Review of Physiology 31: 675-726. https://doi.org/10.1146/annurev.ph.31.030169.003331

HARKER, J. E. (1973): Circadian rhythms in insects. In: MiLls, J. N. (ed.): Biological aspects of circadian rhythms. Plenum Press, London and New York, pp. 189-233. https://doi.org/10.1007/978-14613-4565-7_6

HEAD, G. (1995): Selection on fecundity and variation in the degree of sexual size dimorphism among spider species (class Araneae). Evolution 49: 776-781. https://doi.org/10.1111/j.1558-5646.1995.tb02313.x

HeILING, A. M. (1999): Why do nocturnal orb-web spiders (Araneidae) search for light? Behavioral Ecology and Sociobiology 46: 43-49. https://doi.org/10.1007/s002650050590

Heiling, A. M. \& Herberstein, M. E. (1998): Activity patterns in different developmental stages and sexes of Larinioides sclopetarius (Clerck) (Araneae, Araneidae). In: SELDEN, P. A. (ed.): Proceedings of the $17^{\text {th }}$ European Colloquium of Arachnology, Edinburgh 1997. British Arachnological Society, Burnham Beeches, Bucks, pp. 211-214).

Herberstein, M. E. \& Elgar, M. A. (1994): Foraging strategies of Eriophora transmarina and Nephila plumipes (Araneae: Araneoidea): Nocturnal and diurnal orb-weaving spiders. Australian Journal of Ecology 19: 451-457. https://doi.org/10.1111/j.1442-9993.1994.tb00511.x

HoPE, P. R. \& JONES, G. (2013): An entrained circadian cycle of peak activity in a population of hibernating bats. Journal of Mammalogy 94: 497-505. https://doi.org/10.1644/12-MAMM-A-095.1

Hut, R. A., Kronfeld-Schor, N., van DER Vinne, V. \& De LA Iglesia, H. (2012): In search of a temporal niche: environmental factors. Progress in Brain Research 199: 281-304. https://doi.org/10.1016/B978-0-444-59427-3.00017-4

Hut, R. A., Paolucci, S., Dor, R., Kyriacou, C. P. \& DaAn, S. (2013): Latitudinal clines: an evolutionary view on biological rhythms. Proceedings of the Royal Society B 280: 20130433. https://doi.org/10.1098/rspb.2013.0433

Hut, R. A., Pilorz, V., Boerema, A. S., Strijkstra, A. M. \& DaAn, S. (2011): Working for food shifts nocturnal mouse activity into the day. PloS ONE 6: e17527. https://doi.org/10.1371/journal.pone.0017527

Ingle, K., Horváth, Á., Gallé-SzPisjak, N., Gellért, L., Csata, E. \& Gallé, R. (2018): The effects of overwintering and habitat type on body condition and locomotion of the wolf spider Pardosa alacris. Acta Oecologica 89: 38-42. ttps://doi.org/10.1016/j.actao.2018.05.002

Jones, T. C., Akoury, T. S., Hauser, C. K. \& Moore, D. (2011): Evidence of circadian rhythm in antipredator behaviour in the orb-weaving spider Larinioides cornutus. Animal Behaviour 82: 549-555. https://doi.org/10.1016/j.anbehav.2011.06.009 
Jones, T. C., Wilson, R. J. \& Moore, D. (2018): Circadian rhythms of locomotor activity in Metazygia wittfeldae (Araneae: Araneidae). Journal of Arachnology 46: 26-30. https://doi.org/10.1636/JoA-S-17-036.1

KISS, B. \& SAMU, F. (2002): Comparison of autumn and winter development of two wolf spider species (Pardosa, Lycosidae, Araneae) having different life history patterns. Journal of Arachnology 30: 409-415. https://doi.org/10.1636/0161-8202(2002)030[0409:COAAWD]2.0.CO;2

Ko, C. H. \& TAKAHASHI, J. S. (2006): Molecular components of the mammalian circadian clock. Human Molecular Genetics 15: R271-R277. https://doi.org/10.1093/hmg/ddl207

KOUKKARI, W. L. \& SOTHERN, R. B. (2006): Introducing biological rhythms. Springer Science + Business Media Inc, New York, 655 pp.

Kovoor, J., Ortega-Escobar, J. \& MuÑz-Cuevas, A. (1999): Circadian structural changes in the retina of Lycosa tarentula (Araneae: Lycosidae). Biological Rhythm Research 30: 407-423. https://doi.org/10.1076/brhm.30.4.407.1412

Król, A., Hajdamowicz, I. \& Tkaczuk, C. (2018): Diel and seasonal activity of ground dwelling spiders (Araneae) in a sandy grassland habitat. Turkish Journal of Zoology 42: 439-448. https://doi.org/10.3906/zoo-1802-46

Kronfeld-SChOR, N. \& DAYAN, T. (2003): Partitioning of time as an ecological resource. Annual Review of Ecology, Evolution, and Systematics 34: 153-181. https://doi.org/10.1146/annurev.ecolsys.34.011802.132435

Kronfeld-Schor, N., Bloch, G. \& Schwartz, W. J. (2013): Animal clocks: when science meets nature. Proceedings of the Royal Society B 280: 20131354. https://doi.org/10.1098/rspb.2013.1354

Krumpalova, Z. \& TuF, I. H. (2013): Circadian rhythms of ground living spiders: mechanisms of coexistence strategy based on the body size. Polish Journal of Ecology 61: 575-586.

LAZZARI, C. R. \& Insausti, T. C. (2008): Circadian rhythms in insects. In: FAnJul-Moles, M. L. \& Roblero, R. A. (eds.): Comparative Aspects of Circadian Rhythms. Transworld Research Network, Trivandrum, pp. 75-92.

LEISE, T. L. (2013): Wavelet analysis of circadian and ultradian behavioral rhythms. Journal of Circadian Rhythms 11: 5. https://doi.org/10.1186/1740-3391-11-5

Lundgren, J. G., Nichols, S., Prischmann, D. A. \& Ellsbury, M. M. (2009): Seasonal and diel activity patterns of generalist predators associated with Diabrotica virgifera immatures (Coleoptera: Chrysomelidae). Biocontrol Science and Technology 19: 327-333. https://doi.org/10.1080/09583150802696533

Maloney, D., Drummond, F. A. \& Alford, R. (2003): TB190: Spider predation in agroecosystems: can spiders effectively control pest populations?. Maine Agricultural and Forest Experiment Station, The University of Maine, Orono, $32 \mathrm{pp}$.

Mammola, S., Michalik, P., Hebets, E. A., \& Isaia, M. (2017): Record breaking achievements by spiders and the scientists who study them. PeerJ 5: e3972. https://doi.org/10.7717/peerj.3972

MARC, P. (1991): Interspecific and intraspecific interactions between spider species from apple orchards. Bulletin de la Société Neuchâteloise des Sciences Naturelles 116: 177-184.

MARC, P., CANARD, A. \& YSNEL, F. (1999): Spiders (Araneae) useful for pest limitation and bioindication. Agriculture, Ecosystems and Environment 74: 229-273. https://doi.org/10.1016/S01678809(99)00038-9

Marler, M. R., Gehrman, P., Martin, J. L. \& Ancoli-Israel, S. (2006): The sigmoidally transformed cosine curve: a mathematical model for circadian rhythms with symmetric non-sinusoidal shapes. Statistics in Medicine 25: 3893-3904. https://doi.org/10.1002/sim.2466 
Marshall, S. D., Pavuk, D. M. \& Rypstra, A. L. (2002): A comparative study of phenology and daily activity patterns in the wolf spiders Pardosa milvina and Hogna helluo in soybean agroecosystems in southwestern Ohio (Araneae, Lycosidae). Journal of Arachnology 30: 503-510. https://doi.org/10.1636/0161-8202(2002)030[0503:ACSOPA]2.0.CO;2

McGregor, A. P., Hilbrant, M., Pechmann, M., Schwager, E. E., Prpic, N. M. \& Damen, W. G. M. (2008): Cupiennius salei and Achaearanea tepidariorum: spider models for investigating evolution and development. BioEssays 30: 487-498. https://doi.org/10.1002/bies.20744

MCQueEN, D. J. \& CuliK, B. (1981): Field and laboratory activity patterns in the burrowing wolf spider Geolycosa domifex (Hancock). Canadian Journal of Zoology 59: 1263-1271. https://doi.org/10.1139/z81-178

Menegazzi, P., Vanin, S., Yoshit, T., Rieger, D., Hermann, C., Dusik, V., Kyriacou, C. P., Helfrich-Förster, C. \& Costa, R. (2013): Drosophila clock neurons under natural conditions. Journal of Biological Rhythms 28: 3-14. https://doi.org/10.1177/0748730412471303

Mestre, L., Garcia, N., Barrientos, J. A., Espadaler, X. \& Piñol, J. (2013): Bird predation affects diurnal and nocturnal web-building spiders in a Mediterranean citrus grove. Acta Oecologica 47: 74-80. https://doi.org/10.1016/j.actao.2013.01.001

MezöFi, L., Markó, G., KovÁCs, P. \& MARKó, V. (2019): Circadian rhythms in the locomotor activity of the spiders Carrhotus xanthogramma (Salticidae) and Philodromus cespitum (Philodromidae): Temporal patterns and sexual differences. European Journal of Entomology 116: 158-172. https://doi.org/10.14411/eje.2019.017

MezöFi, L., Markó, G., Nagy, Cs., Korányi, D. \& Markó, V. (2020): Beyond polyphagy and opportunism: natural prey of hunting spiders in the canopy of apple trees. PeerJ 8: e9334. https://doi.org/10.7717/peerj.9334

MiLls, J. N. (ed.) (1973): Biological aspects of circadian rhythms. Plenum Press, London and New York, 319 pp. https://doi.org/10.1007/978-1-4613-4565-7

Minors, D. S. \& WATERhouse, J. M. (1986): Circadian rhythms and their mechanisms. Experientia 42: 1-13. https://doi.org/10.1007/BF01975875

Minors, D. S. \& WAterhouse, J. M. (1988): Mathematical and statistical analysis of circadian rhythms. Psychoneuroendocrinology 13: 443-464. https://doi.org/10.1016/0306-4530(88)90030-3

Moore, D., Watts, J. C., Herrig, A. \& Jones, T. C. (2016): Exceptionally short-period circadian clock in Cyclosa turbinata: regulation of locomotor and web-building behavior in an orb-weaving spider. Journal of Arachnology 44: 388-396. https://doi.org/10.1636/JoA-S-16-014.1

Morse, D. H. (1981): Prey capture by the crab spider Misumena vatia (Clerck) (Thomisidae) on three common native flowers. American Midland Naturalist 105: 358-367. https://doi.org/10.2307/2424754

Mrosovsky, N. (1996): Locomotor activity and non-photic influences on circadian clocks. Biological Reviews 71: 343-372. https://doi.org/10.1111/j.1469-185X.1996.tb01278.x

Mrosovsky, N. (1999): Masking: history, definitions, and measurement. Chronobiology International 16: 415-429. https://doi.org/10.3109/07420529908998717

Muñoz-Cuevas, A., Carricaburu, P. \& Kovoor, J. (1998): Comparative electroretinography of Peucetia gerhardi and Peucetia graminea (Araneae: Oxyopidae). In: SELDEN, P. A. (ed.): Proceedings of the $17^{\text {th }}$ European Colloquium of Arachnology, Edinburgh 1997. British Arachnological Society, Burnham Beeches, Bucks, pp. 143-150. 
Naitoh, P., Englund, C. E. \& Ryman, D. H. (1985): Circadian rhythms determined by cosine curve fitting: Analysis of continuous work and sleep-loss data. Behavior Research Methods, Instruments, \& Computers 17: 630-641. https://doi.org/10.3758/BF03200975

NAKAMURA, T. \& YAMASHITA, S. (1997): Phototactic behavior of nocturnal and diurnal spiders: negative and positive phototaxes. Zoological Science 14: 199-203. https://doi.org/10.2108/zsj.14.199

NørgaArd, T., Henschel, J. R. \& Wehner, R. (2006): The night-time temporal window of locomotor activity in the Namib Desert long-distance wandering spider, Leucorchestris arenicola. Journal of Comparative Physiology A 192: 365-372. https://doi.org/10.1007/s00359-005-0072-7

ORTEGA-EsCOBAR, J. (2002): Circadian rhythms of locomotor activity in Lycosa tarentula (Araneae, Lycosidae) and the pathways of ocular entrainment. Biological Rhythm Research 33: 561-576. https://doi.org/10.1076/brhm.33.5.561.13934

Ortega, J., Ruiz, M. \& Fernandez-Montraveta, C. (1992): Daily patterns of locomotor activity in a lycosid spider. Biological Rhythm Research 23: 295-301. https://doi.org/10.1080/09291019209360188

OSAKI, S. \& OSAKI, M. (2011): Evolution of spiders from nocturnal to diurnal gave spider silks mechanical resistance against UV irradiation. Polymer Journal 43: 200-204. https://doi.org/10.1038/pj.2010.119

PEKÁR, S. \& BENEŠ, J. (2008): Aged pesticide residues are detrimental to agrobiont spiders (Araneae). Journal of Applied Entomology 132: 614-622. https://doi.org/10.1111/j.1439-0418.2008.01294.x

PEKÁR, S. \& JARAB, M. (2011): Life-history constraints in inaccurate Batesian myrmecomorphic spiders (Araneae: Corinnidae, Gnaphosidae). European Journal of Entomology 108: 255-260. https://doi.org/10.14411/eje.2011.034

Pewsey, A., Neuhäuser, M. \& Ruxton, G. D. (2013): Circular statistics in R. Oxford University Press, Oxford, $183 \mathrm{pp}$.

Pfannenstiel, R. S. \& Yeargan, K. V. (2002): Identification and diel activity patterns of predators attacking Helicoverpa zea (Lepidoptera: Noctuidae) eggs in soybean and sweet corn. Environmental Entomology 31: 232-241. https://doi.org/10.1603/0046-225X-31.2.232

PitTENDRIGH, C. S. (1960): Circadian rhythms and the circadian organization of living systems. Cold Spring Harbor Symposia on Quantitative Biology 25: 159-184. https://doi.org/10.1101/SQB.1960.025.01.015

Pittendrigh, C. S. (1981): Circadian systems: entrainment. In: Aschoff, J. (ed.): Biological Rhythms. Plenum Press, New York, pp. 95-124. https://doi.org/10.1007/978-1-4615-6552-9_7

Prószynski, J. \& Lubin, Y. (1993): Pitfall trapping of Salticidae (Araneae) in the Negev Desert. Bollettino delle sedute della Accademia Gioenia di Scienze Naturali in Catania 26: 281-291.

RÁDAI, Z., KISS, B. \& BARTA, Z. (2017): Pace of life and behaviour: rapid development is linked with increased activity and voracity in the wolf spider Pardosa agrestis. Animal Behaviour 126: 145151. https://doi.org/10.1016/j.anbehav.2017.02.004

Ranganathan, Y., Ghara, M. \& Borges, R. M. (2010): Temporal associations in fig-wasp-ant interactions: diel and phenological patterns. Entomologia Experimentalis et Applicata 137: 50-61. https://doi.org/10.1111/j.1570-7458.2010.01038.x

REFINETTI, R. (1991): An extremely simple procedure for the analysis of circadian and estrous periodicity. Physiology \& Behavior 50: 655-659. https://doi.org/10.1016/0031-9384(91)90563-4

REFINETTI, R. (1993): Laboratory instrumentation and computing: comparison of six methods for the determination of the period of circadian rhythms. Physiology \& Behavior 54: 869-875. https://doi.org/10.1016/0031-9384(93)90294-P 
RefinetTI, R. (2016): Circadian physiology, $3^{\text {rd }}$ Edition. CRC press, Boca Raton, 714 pp. https://doi.org/10.1201/9781420039016

RefinetTi, R., CoRnÉlissen, G. \& HALbeRG, F. (2007): Procedures for numerical analysis of circadian rhythms. Biological Rhythm Research 38: 275-325. https://doi.org/10.1080/09291010600903692

RUF, T. (1999): The Lomb-Scargle periodogram in biological rhythm research: analysis of incomplete and unequally spaced time-series. Biological Rhythm Research 30: 178-201. https://doi.org/10.1076/brhm.30.2.178.1422

SAKURA, K. \& Numata, H. (2017): Contact with water functions as a Zeitgeber for the circatidal rhythm in the mangrove cricket Apteronemobius asahinai. Biological Rhythm Research 48: 887895. https://doi.org/10.1080/09291016.2017.1319639

Salvestrini, F. M. D. \& Gasnier, T. R. (2001): Differences in the activity of juveniles, females and males of two hunting spiders of the genus Ctenus (Araneae, Ctenidae): active males or inactive females? Journal of Arachnology 29: 276-278. https://doi.org/10.1636/0161-8202(2001)029[0276:SCDITA]2.0.CO;2

SAUNDERS, D. S. (2012): Insect photoperiodism: seeing the light. Physiological Entomology 37: 207218. https://doi.org/10.1111/j.1365-3032.2012.00837.x

Saunders, D. S., Steel, C. G. H., Vafopoulou, X. \& LeWIS, R. D. (2002): Insect Clocks, $3^{\text {rd }}$ Edition. Elsevier, Amsterdam, $560 \mathrm{pp}$.

Schmitt, A., Schuster, M. \& BARTh, F. G. (1990): Daily locomotor activity patterns in three species of Cupiennius (Araneae, Ctenidae): The males are the wandering spiders. Journal of Arachnology 18: 249-255.

SchmiTz, A. (2004): Metabolic rates during rest and activity in differently tracheated spiders (Arachnida, Araneae): Pardosa lugubris (Lycosidae) and Marpissa muscosa (Salticidae). Journal of Comparative Physiology B 174: 519-526. https://doi.org/10.1007/s00360-004-0440-6

SEYFARTH, E. A. (1980): Daily patterns of locomotor activity in a wandering spider. Physiological Entomology 5: 199-206. https://doi.org/10.1111/j.1365-3032.1980.tb00227.x

Sin, A., ZiEMBA, R. \& HARDING, K. C. (2000): New insights on how temporal variation in predation risk shapes prey behavior. Trends in Ecology \& Evolution 15: 3-4. https://doi.org/10.1016/S0169-5347(99)01766-8

Soriano-Morales, S., Caballero-Hernández, O., DÁvila-Montes, M., Morales-Malacara, J. B. \& Miranda-AnAYA, M. (2013): Circadian locomotor activity and entrainment by light cycles in cave spiders (Dipluridae and Ctenidae) at the cave Los Riscos, Qro. México. Biological Rhythm Research 44: 949-955. https://doi.org/10.1080/09291016.2013.781330

STEPHAN, F. K. (2002): The "other" circadian system: food as a Zeitgeber. Journal of Biological Rhythms 17: 284-292. https://doi.org/10.1177/074873002129002591

Sullivan, H. L. \& MoRSE, D. H. (2004): The movement and activity patterns of similar-sized adult and juvenile crab spiders Misumena vatia (Araneae, Thomisidae). Journal of Arachnology 32: 276-283. https://doi.org/10.1636/S03-5

SUTER, R. B. (1993): Circadian rhythmicity and other patterns of spontaneous motor activity in Frontinella pyramitela (Linyphiidae) and Argyrodes trigonum (Theridiidae). Journal of Arachnology 21: 6-22.

SUtER, R. B. \& BENSON, K. (2014): Nocturnal, diurnal, crepuscular: activity assessments of Pisauridae and Lycosidae. Journal of Arachnology 42: 178-191. https://doi.org/10.1636/J13-66.1

SzInETÁR, C. (2000): Data on the biology of Larinia jeskovi Marusik, 1986 (Araneae: Araneidae) from the reed belts of Lake Balaton. Ekológia (Bratislava) 19: 105-110. 
SzinetÁR, C. \& EICHARDT, J. (2004): Larinia species (Araneidae, Araneae) in Hungary. Morphology, phenology and habitats of Larinia jeskovi Marusik, 1986, Larinia elegans Spassky, 1939, and Larinia bonneti Spassky, 1939. In: F. SAMU \& C. SzInETÁr (eds): European Arachnology. Akaprint Kft., Budapest, pp. 179-186.

Tattersall, I. (1987): Cathemeral activity in primates: a definition. Folia Primatologica 49: 200202. https://doi.org/10.1159/000156323

TietJen, W. J. \& CADY, A. B. (2007): Sublethal exposure to a neurotoxic pesticide affects activity rhythms and patterns of four spider species. Journal of Arachnology 35: 396-406. https://doi.org/10.1636/S04-62.1

ToPPING, C. J. \& SundeRLAND, K. D. (1992): Limitations to the use of pitfall traps in ecological studies exemplified by a study of spiders in a field of winter wheat. Journal of Applied Ecology 29: 485-491. https://doi.org/10.2307/2404516

TORK P. (2018): Temporal behavior in jumping spiders (Araneae, Salticidae). PhD Thesis. University of Canterbury, Christchurch, $142 \mathrm{pp}$.

UetZ, G. W. \& UnZickeR, J. D. (1976): Pitfall trapping in ecological studies of wandering spiders. Journal of Arachnology 3: 101-111.

Uetz, G. W., Hieber, C. S., Jakob, E. M., Wilcox, R. S., Kroeger, D., McCrate, A. \& Mostrom, A. M. (1994): Behavior of colonial orb-weaving spiders during a solar eclipse. Ethology 96: 24-32. https://doi.org/10.1111/j.1439-0310.1994.tb00878.x

USNO. (2018): Rise, set, and twilight definitions. United States Naval Observatory (USNO) Astronomical Applications Department. http://aa.usno.navy.mil/faq/docs/RST_defs.php (megtekintés 2018. jan. 24.)

Vanin, S., Bhutani, S., Montelli, S., Menegazzi, P., Green, E. W., Pegoraro, M., Sandrelli, F., Costa, R. \& Kyriacou, C. P. (2012): Unexpected features of Drosophila circadian behavioural rhythms under natural conditions. Nature 484: 371-375. https://doi.org/10.1038/nature10991

Vetter, R. S., Penas, L. M. \& Hoddle, M. S. (2017): Effect of seasonal photoperiod on molting in Loxosceles reclusa and Loxosceles laeta spiders (Araneae: Sicariidae). Journal of Arachnology 45: 277-282. https://doi.org/10.1636/JoA-S-16-043.1

WALKer, S. E., MARshall, S. D., RyPSTRA, A. L. \& TAYLOR, D. H. (1999): The effects of hunger on locomotory behaviour in two species of wolf spider (Araneae, Lycosidae). Animal Behaviour 58 : 515-520. https://doi.org/10.1006/anbe.1999.1180

WARD, D. \& LuBIN, Y. (1992): Temporal and spatial segregation of web-building in a community of orb-weaving spiders. Journal of Arachnology 20: 73-87.

WatTs, J. C., Ross, C. R. \& Jones, T. C. (2015): Diel and life-history characteristics of personality: consistency versus flexibility in relation to ecological change. Animal Behaviour 101: 43-49. https://doi.org/10.1016/j.anbehav.2014.12.020

Welch, K. D. \& HARwood, J. D. (2014): Temporal dynamics of natural enemy-pest interactions in a changing environment. Biological Control 75: 18-27. https://doi.org/10.1016/j.biocontrol.2014.01.004

WCISLO, W. T. \& TIERNEY, S. M. (2009): Behavioural environments and niche construction: the evolution of dim-light foraging in bees. Biological Reviews 84: 19-37. https://doi.org/10.1111/j.1469185X.2008.00059.X

Wolf, E. (2011): Diel periodicity in activity and location in the web of the common house spider (Achaearanea tepidariorum). East Tennessee State University, Undergraduate Honors Thesis Series, Paper 13. http://dc.etsu.edu/honors/13 (megtekintés 2020. jan. 30.) 
MEZŐFI L.

Ximenez-Embun, M. G., Zaviezo, T. \& GreZ, A. (2014): Seasonal, spatial and diel partitioning of Acyrthosiphon pisum (Hemiptera: Aphididae) predators and predation in alfalfa fields. Biological Control 69: 1-7. https://doi.org/10.1016/j.biocontrol.2013.10.012

YAMASHitA, S. (2002): Efferent innervation of photoreceptors in spiders. Microscopy Research and Technique 58: 356-364. https://doi.org/10.1002/jemt.10143

YAMASHITA, S. \& NAKAMURA, T. (1999): Circadian oscillation of sensitivity of spider eyes: diurnal and nocturnal spiders. Journal of Experimental Biology 202: 2539-2542. https://doi.org/10.1016/S1095-6433(99)90554-8

Zurek, D. B., Cronin, T. W., Taylor, L. A., Byrne, K., Sullivan, M. L. G. \& Morehouse, N. I. (2015): Spectral filtering enables trichromatic vision in colorful jumping spiders. Current Biology 25: R403-R404. https://doi.org/10.1016/j.cub.2015.03.033 


\title{
Current knowledge of circadian rhythms in spiders (Araneae) - Ecological aspects, methods in research and data analysis techniques
}

\section{LÁSZLÓ MEZŐFI}

\author{
Plant Protection Institute, Szent István University, Ménesi út 44, H-1118 Budapest, Hungary \\ E-mail:mezofilaszlo@gmail.com
}

\section{ÁLLATTANI KÖZLEMÉNYEK (2020) 105(1-2): 115-141.}

\begin{abstract}
This chronobiological 'crash-course' introduces the reader to the hidden world of biological rhythm research. Firstly, we review the major rules and technical terms of this discipline and we discuss the ecological aspects and types of adaptation to different temporal niches in animals. Then through the example of spiders (Araneae) we show in more detail what is known about the activity rhythms and diel activity of this group, and how these rhythms can be studied in the laboratory or under natural conditions. Finally, we briefly survey which methods/data analysis techniques can be used for proper evaluation of various biological rhythms.
\end{abstract}

Keywords: chronobiology, diel rhythm, locomotor activity, review, terminology. 